\title{
İnsani Gelişme Endeksi ve Alt Endekslerinin Türkiye'deki İller İçin Ölçülmesi
}

\author{
Mustafa Caner Meydan \\ Sanayi ve Teknoloji Uzmanı
}

\author{
Volkan İdris Sarı \\ Sanayi ve Teknoloji Uzmanı
}

Öz

Ekonomik büyüme ile kalknnma arasındaki ilişki kalknnma iktisadının temel tartışma konularıdan birisi olmuştur. Ekonomik büyüme rakamlarmm ülkelerin yaşam kalitesi, mutluluk, sürdürülebilirlik, yapabilirlik ve kapasite bakımindan karşılaştırlmasına uygun olmadığı yönünde yaklaşımlar ortaya konulmuştur. Bunun çözümü için de farklı ölçüm ve analiz teknikleri önerilmiştir. İnsani gelişmişlik endeksi de bu amaca hizmet eden basit ama etkili bir araç olarak uluslararası alanda kendine önemli bir yer bulmuştur. Birleşmiş Milletler Kalkınma Programı tarafindan 1990 yllindan itibaren her yll hesaplanan insani gelişme endeksi ile ülkelerin kalkınma, yoksulluk, cinsiyet eşitlĭ̆i, gelir eşitsizliğ̌i gibi konularda karş̧laştırılabilmesine imkân tanınmaktadır. Endeksin sinırl sayıda gösterge kullanarak kapsaml analizlere imkân vermesi bu çalışmadaki yöntemin sadece ülkeleri karşılaştrrmak için değil ülke içindeki farkh idari birimlerin de gelişmişlik düzeylerini ölçmek için kullanılmasına imkân tanımıştır. Bu çalı̧mada 2014 yılı verileri kullanılarak il bazında insani gelişme endeksi ve alt endeksleri üretilmekte ve insani gelişme endeksi ile diğer alt endekslerin arasındaki ilişki analiz edilmektedir. Sonuç olarak, insani gelişme endeksinin Türkiye'nin batısında doğusuna göre daha yüksek değer aldığı görülmüştür. Ayrıca, insani gelişme endeksi ile gelir ve eğitim alt endeksleri arasında istatistiki güçlü ve anlamlı bir ilişki bulunmuştur.

Anahtar Kelimeler: İnsani gelişme, eğitim, sağllk, gelir, il, endeks 


\title{
Measuring Human Development Index and Sub-Indices for Turkish Provinces
}

\author{
* \\ Mustafa Caner Meydan \\ Industry and Technology Specialist \\ Volkan İdris Sarı \\ Industry and Technology Specialist
}

\begin{abstract}
The relation between economic growth and development is one of the main discussion topics of the development economics. There are some arguments claiming that economic growth indicators are not proper tools to measure differences among countries in terms of quality of life, happiness, sustainability, capabilities and capacities. In order to fix this problem several measurement and analysis techniques are proposed. Human development index, which is one of the simple yet effective tools, has become prominent in international fora in this regard. United Nations Development Program's human development index (HDI) compares countries in terms of development, poverty, gender equality, income inequality, etc. since 1990. As the index enables comprehensive analyses by using a few variables, it could be used not only for comparing countries but also measuring the development levels of different provinces within a country. This study calculates city-level human development index and sub-indexes by using 2014 data for Turkey. Moreover, relations between sub-indexes and human development index are analyzed. As a conclusion, it is observed that human development indexes on the West is higher than on the East part of Turkey. In addition, a statistically strong and meaningful relationship was found between the HDI and income and education sub-indices.
\end{abstract}

Keywords: Human development, education, health, income, province, index 


\section{Giriş}

Birleşmiş Milletler Kalkınma Programı (UNDP) tarafından geliştirilen ve 1990 yılından itibaren her yıl 150'den fazla ülkeyi karşılaştırmak için yayımlanan İnsani Gelişme Endeksi (İGE) sağladığı uluslararası karşılaştırma imkanı nedeniyle ülkelerin gündeminde yer almayı başarmıştır. Endeks değeri ve ülke sıralamasının yıllar itibarıyla yaşadığı değişimler ile alt endeksler bazındaki gerçekleşmeler ulusal ve uluslararası kuruluşlar tarafından takip edilmektedir. İGE'nin istikrarlı bir şekilde güncellenmesi ve her yıl farklı bir tema ile kamuoyuna duyurulması bu ilgiyi artırmaktadır. Örneğin; 2014 yılında "Kırılganlıkların Azaltılması ve Dayanıklılığın Sağlanması" (UNDP, 2014), 2015 yılında "İnsani Gelişme için Çalışma" (UNDP, 2015b) ve 2016 yılında "Herkes için İnsani Gelişme" (UNDP, 2016a) temaları kullanılmıştır.

İGE, uluslararası karşılaştırmanın yanında kullandığı yöntem ve veriler ile ülke içindeki insani gelişmişlik farklarının ölçülmesi için de kullanışlı bir araçtır. Bu çerçevede UNDP, ülkelerin karşılaştırılmasını sağlayan genel raporların yanında ülke raporları ile bölgeler ve iller için de endeks değerlerini hesaplamıştır. Akder (1994) ulus-altı düzeyde yürütülen İGE çalışmalarına örnek olarak Brezilya, Çin, Mısır, Hindistan, İran, Malezya, Meksika, Polonya, Türkiye ve Amerika Birleşik Devletleri'ni (ABD) vermiştir. İGE'nin ulus-altı düzeyde ele alınması özellikle bölgesel farklılıkların tespiti açısından önemlidir. Bölgesel gelişme farklılıklarının olduğu ülkelerde, insani gelişme düzeyi ülkenin her yerinde aynı seviyede değildir. Çin, Portekiz, Hindistan ve İran gibi bölgesel gelişme farklılıklarına sahip ülkelerde ulus-altı düzeyde İGE çalışmaları bu farklılıkların tespitine ilişkin alternatif bir yöntem olarak kullanılmıştır (Akder, 1994; Noorbakhash, 2003; Basu ve Basu, 2005; Noorbakhash, 2005). Bu çalışmalarda aynı ülkenin farklı bölgelerinde İGE ya da alt endeksler itibarıyla "çok yüksek" ve "düşük" insani gelişme düzeyleri aynı anda gözlemlenmektedir.

Ülkemizde bölgesel gelişme farklılıkları 1960'larla başlayan planlı dönemin ana gündem maddelerinden birisi olmuş ve dönemsel değişimlere rağmen günümüze kadar önemini korumuştur (Kalkınma Bakanlığı, 2014, s.79). Bu nedenle bölgesel gelişme farklılıklarının tespiti ve bu farklılıkların azaltılmasına yönelik çeşitli analizler ve politika araçları geliştirilmiştir. Politika araçlarının başarısı mevcut durumun tespitinin doğru yapılabilmesi 
ile doğrudan ilişkilidir. Bu açıdan bölgesel ve yerel düzeydeki İGE hesapları bölgesel farklılıkların tespitine ilişkin önemli bilgiler sağlamaktadır.

Türkiye'de iller bazında İGE başlığında Birleşmiş Milletler' in (BM) metodolojileri kullanılarak daha önce de benzer çalışmalar yapılmıştır. 2001 ve 2004 Türkiye İnsani Gelişme Raporlarında (İGR), Türkiye' nin iller itibarıyla insani gelişme trendleri yer almaktadır (UNDP, 2001; UNDP, 2005). İl bazında gelir verilerinin TÜIK tarafından yeniden yayımlanması sonucunda 2014 yılı verileri ile İGE hesapları güncellenebilir hale gelmiştir. Daha önce GSYİH verilerinin çeşitli "proxy yöntemleri" ile tahmin edilmesi ile gerçekleştirilen gelir endeksi hesaplamalarının doğrudan TÜİK verileri kullanılarak yapılabilme imkânı oluşmuştur. Bu kapsamda, çalışmada en güncel veri olan 2014 yılı verileriyle İGE ve eğitim, sağlık ve gelir alt endeksleri UNDP'nin güncel metodolojisi kullanılarak Türkiye'nin 81 ili için hesaplanması amaçlanmıştır. Çalışma kapsamında, SPSS, Stata ve Microsoft Excel programlarından yararlanılmıştır.

$\mathrm{Bu}$ çalışma ile önceki çalışmalara göre çeşitli iyileştirmeler yapılmıştır. İlk olarak TÜIKK tarafından 2001 yılından sonra ilk defa 2016 yılında 20042014 dönemine ait yayımlanan kişibaşı gayri safi yurtiçi hasıla (GSYİH) verileri kullanılmıştır. Ayrıca, yükseköğretim hariç ve dâhil olarak beklenen okullaşma yılına dayanarak iki farklı İGE hesaplanmıştır ${ }^{1}$. Ülkeler bazında üretilen İGE'nin illere göre hesaplanmasının yanında endeksler arası ilişkiler de analiz edilerek söz konusu ilişkiler yorumlanmış, sağlık ve gelir endeksine dair öneriler geliştirilmiştir.

\section{Kavramsal Çerçeve ve İGE'nin Tarihsel Gelişimi}

Yakın zamana kadar politika yapıcıların temel amacı toplumsal bir hedef olan kalkınmanın sağlanması idi. Kalkınma düzeyinin ölçülmesinde de genellikle GSYİH gibi salt ekonomi odaklı göstergeler kullanılmaktaydı. Bu yaklaşımın altında ekonomik imkanları yüksek olan bireylerden oluşan toplulukların gelişmiş/kalkınmış olduğu varsayımı yatmaktadır.

Bununla birlikte ülkelerin büyümesi (ekonomik) ile gelişme/kalkınma kavramlarının aynı olmadığı net olarak ortaya konulmuştur (Todaro ve

\footnotetext{
${ }^{1}$ BM yükseköğretim hariç okullaşma değerlerini dikkate alarak analizlerini açıkladığı için standart sağlamak adına yükseköğretim hariç okullaşma verileri ile elde edilen analiz sonuçları yayımlanmıştır.
} 
Smith, 2012, s.15). Günümüzde ise bir yandan topyekün toplumsal kalkınma yaklaşımı, yerini bireysel yaşam kalitesinin artırılması hedefine bırakırken diğer yandan gelirin toplum içindeki dağılımı, temel hizmetlere erişim imkânları ve insanların kapasitesi gibi konular gündeme gelmeye başlamıştır. Ayrıca, bireyleri dikkate almayan ve salt ekonomik performansa bağlı verilerin insanların gerçekte yaşadıkları durumu açılamak için yetersiz kaldığı görülmüştür (Seers, 1969, s.10). Çünkü ekonomik gelişmede mesafe kaydeden birçok gelişmekte olan ülke sosyal sorunların çözümünde aynı başarıyı gösterememiştir. Diğer bir ifadeyle genellikle milli hasıla hesaplarına dayanan ekonomik göstergeler insani kalkınmanın çok boyutlu yapısını yansıtmamaktadır (Miles, 1985, s.34). Bu çıkarım, politika yapıcıları ve araştırmacıları insani gelişmişlik ile ekonomik gelişme arasındaki ilişkileri yeniden ele almaya itmiştir.

Bu konudaki arayışlara öncülük eden kişilerden birisi de hem bir düşünür hem de bir politika yapıcı olan Mahbub-ul Haq olmuştur (Gasper, 2011, s.433). Haq, Amartya Sen'in yapabilirlikler yaklaşımını esas alarak insanların refah seviyesini ölçmek için yeni bir model önermiştir. Böylelikle Sen'in yaklaşımı İGE'nin felsefi altyapısını oluşturmuştur.

İGE'nin amacı, temel kabiliyetleri itibarıyla insanların yapabilirliklerinin ölçülmesi yoluyla sadece parasal ölçütlerle gelişmişliği açıklayan yaklaşımlara karşı bir alternatif oluşturmaktır (Anand ve Sen, 1997, s.3). İGE, kişi başına milli hasıla hesaplarının iyi bir gelişmişlik göstergesi olmadığını savunmaktadır. Çünkü bu gösterge; gelir dağılımı farklılıkları, yoksulluk, yoksunluk, gelirin hanehalkları tarafından kullanılış biçimi ve gelir ile ölçülemeyecek sosyal faktörler için yeterli bilgi üretememektedir.

İGR'ler, insani gelişme kavramını gelir hesaplarının ötesine taşıyarak insan kaynaklarının gelişimini, insanı insan yapan özgürlük yaklaşımını ve insanın temel gereksinimlerini bir arada ölçmekte ve kalkınmaya insan boyutunu katmaktadır (Demir, 2006, s.2). İGE çerçevesinde insani gelişme, bireylerin seçme kapasitelerinin geliştirilmesi olarak tanımlanmaktadır (Demir Şeker, 2011, s.1). Bu model önerisinde bir yandan ekonomik gelişme ile insani gelişmişlik arasındaki farkın açıklanması diğer yandan da basit ve sürdürülebilir bir ölçüm altyapısının oluşturulması hedeflenmiştir.

İlk kez 1990 yılında geliştirilen İGE geçen dönemde yapılan tüm eleştirilere rağmen dünyada ülkelerin sosyo-ekonomik gelişmişlik düzeyine ilişkin mukayeselerde en çok kullanılan araç haline gelmiştir. 25 yılı aşan İGE tecrübesi bize gelirin insani gelişmişlik açısından gerekli olduğunu ancak 
yeterli olmadığını göstermiştir. Gelir düzeyi yüksek olan birçok ülke (Kuveyt, Gabon, Katar) düşük İGE değerlerine sahipken, düşük gelirli bazı ülkeler (Küba, Gürcistan ve Ukrayna) görece yüksek İGE değerlerine sahiptir. Zira, yaşam kalitesinin ölçülmesine katkı verebilecek, aynı zamanda tüm ülkeler için temin edilebilecek ortak bir değişken seti bulmak oldukça güçtür. Esasında, gelir üzerinden gelişmişliğin ölçülmesi gelir verisinin hem kolay ölçülebilir hem de kolay erişilebilir olması ile de ilgilidir. Bu nedenle model önerisi için ilk aşamada aşağıdaki altı temel ilke benimsenmiştir (Haq, 1995, s.47):

- İnsani gelişmişliğin ölçülmesi sürecine insanların seçme kapasitelerini eklemek,

- Basit ve yönetilebilir bir çalışma için az sayıda gösterge kullanmak,

- Birçok alt endeks yerine bileşik bir endeks üretmek,

- Sosyal ve ekonomik tercihleri birlikte ele almak,

- Kapsam ve yöntem bakımından yeniliklere açık olmak, esnek ve yenilenebilir olmak,

- Güvenilir ve güncel veri serilerinin yokluğunda bile uygulanabilir olmak.

Bu ilkeler çerçevesinde oluşturulan İGE başlangıçta gelişmişliğin üç boyutu olarak gördüğü uzun ve sağlıklı ömür, bilgi ve yaşam standardını eşit ağırlıklı olarak ölçmekteydi. Üç öğenin her biri insanların seçme olanaklarına karşılık gelmektedir. Sağlıklı yaşam seçim yapabilmenin ön şartıdır. Bilgili olmak ve bilgiye erişebilmek seçenekleri genişletmektedir. Gelir ise seçim yapabilmenin temel kaynağıdır (Tekeli, 2010, s.106).

Başlangiçta tüm göstergelerin minimum ve maksimum değerleri hesaplanmış ve her bir boyut (eğitim, sağlık ve gelir) için bir alt endeks elde edilmiştir. Bu çerçevede, İGE hesaplarında kullanılan veriler genel anlamda bir süreklilik arz etmekle birlikte zaman içinde göstergelerin sayısı, tanımı ve hesaplanma yöntemleri ile ağırlıklarında revizyonlar yapılmıştır (UNDP, 2015a, s.32-34). Sağlık bileşeni dışındaki göstergelerin hesap yöntemi sıklıkla değişmiştir. Buna bağlı olarak ülke verilerinin yıllar itibarıyla karşılaştırılabilirliğini sağlamak ve endeks serisinde kırılmalara neden olmamak adına en son formül kullanılarak geçmiş dönem endeksleri güncellenerek 5'er yıllık dönemler itibarıla sunulmaktadır. Yıllar itibarıyla İGE hesap yönteminde yapılan değişiklikler Ek-1'de yer almaktadır.

İGE'nin oluşturulması aşamasında ortaya konulan yukarıdaki ilke kararları kullanışlı bir endeks üretilmesini sağlamıştır. Buradaki en temel ba- 
şarıyı ise gösterge sayısı ve ağırlıkları ile ilgili tartışmalardan ziyade temelde ölçmek istediği gelişmişliğin boyutlarına olan bağl1lığı ve bunların daha iyi ölçülmesi yönündeki çabalar oluşturmuştur. Az sayıda göstergenin tercih edilmesi ile endekse dâhil edilen tüm ülkeler için veri toplanması kolaylaşmıştır. Kompleks göstergelerin gelişmekte olan ülkelerden temin edilmesindeki zorluktan dolayı az sayıdaki temel göstergelerin kullanılmasina devam edilmektedir.

Ana ilkeleri çerçevesinde, İGE gelişmişliğin diğer boyutlarını ana endeksi değiştirerek incelememiştir. Bunun yerine çok sayıda alt endeks üretimine başlanmıştır. Yoksulluk, cinsiyet eşitliği, gelir dağılımı gibi toplumsal yönü önemli olan boyutlar için detaylı endeks çalışmaları yapılmıştır (Tablo 1).

Tablo 1. Yillar İtibarıyla Hesaplanan Yeni Endeksler

\begin{tabular}{ll}
\hline Y1l & İlave Endeksin Adı \\
\hline 1990 & İGE \\
\hline 1991 & Cinsiyete Duyarlı İGE \\
\hline 1991 & Dağllım Ayarlamalı İGE \\
\hline 1991 & İnsani Özgürlük Endeksi \\
\hline 1992 & Politik Özgürlük Endeksi \\
\hline 1993 & Gelir Dağıllımına Göre Uyarlanmış İGE \\
\hline 1993 & Seçilmiş Göstergeler İle Ülke Raporları \\
\hline 1995 & Toplumsal Cinsiyete Bağlı Gelişme Endeksi \\
\hline 1995 & Toplumsal Cinsiyeti Güçlendirme Endeksi \\
\hline 1997 & İnsani Yoksulluk Endeksi \\
\hline 2010 & Eşitsizliğe Duyarlı İE \\
\hline 2010 & Toplumsal Cinsiyet Esitsizlĭgi Endeksi \\
\hline
\end{tabular}

Kaynak: UNDP (2017a)

1992 yılından sonra ülkeler için detaylı raporlar hazırlanmış ve ülke içindeki gelişmişlik farklılıklarını açıklayan çalışmalar yapılmıştır. Bunlardan bir tanesi de 1992 yılında Türkiye için “İnsanca Gelişme Birinci Türkiye Konferansi Raporu"dur (UNDP, 1992).

BM'nin 2010 yılından sonra güncellediği metodolojiye göre İGE boyutları; uzun ve sağlıklı yaşam, eğitim ve yaşam standartlarıdır. İlgili başlıklar için doğumda beklenen yaşam süresi, beklenen ve ortalama okullaşma yılı ile kişi başı GSYİH verileri kullanılmaktadır.

$$
\dot{\mathrm{IGE}}=(\text { Sağllk Endeksi }+ \text { Eğitim Endeksi }+ \text { Gelir Endeksi })^{1 / 3}
$$


Bu formülasyon ile İGE endeks değeri 0 ile 1 arasında değerler alabilmektedir. 1'e yakın değerler yüksek insani gelişmişliği, 0'a yakın değerler ise düşük insani gelişmişliği göstermektedir.

\section{İnsani Gelişme Endeksine Yöneltilen Temel Eleştiriler}

Endekse yöneltilen eleştirilerin önemli bir kısmı seçilen alt bileşenler ve bunların ölçümüne ilişkin göstergeler ile bu bileşenlerin sonuçlarının tek bir endekse indirgenme süreci ile ilgilidir. En temel eleştiri yaşam kalitesinin eğitim ve sağlık göstergelerine indirgenmesidir. Eğitim ve sağlığın dışında; eşitlik, siyasi özgürlük, insan hakları, sürdürülebilirlik ve mutluluk gibi kavramlar İGE'ye dahil edilmemiştir. Bu eleştiri UNDP tarafından İGE'ye ilave olarak hazırlanan Tablo 1'deki tamamlayıcı endeksler ile karşılanmaya çalışılmıştır.

İGE'ye yöneltilen diğer bir eleştiri ise, sonuç göstergeleri ile mevcut gelişmişlik düzeyinin ölçülmesidir. Endeks için kullanılan sonuç göstergelerinin ancak geçmiş dönemdeki ilerlemeleri yansıtacağı ve sonuçların mevcut durumu izah etmekten uzak olduğu değerlendirilmektedir (Kovacevic, 2010, s. 6). Örneğin, 2015 yılı endeksi 2010 yılına kadar eğitim ve sağlıkta yapılan düzenlemeleri ya da tercih edilen politikaları yansitabilmektedir. Bu eleştirilere karşın İGE'nin yıllık raporlarla yayımlanması ve uzun soluklu yapısı mevcut politikaların endeks değeri üzerindeki etkilerinin takip edilmesini ya da tahmin edilebilmesini kolaylaştırmaktadır.

Diğer bir eleştiri ise eğitim ve sağlık alanında seçilen göstergelerin o alandaki seçme kapasitelerini sınırlı bir şekilde yansıtabilmesidir. Örneğin, doğumda beklenen yaşam süresi insanların yaşadıkları sürede sağlıklı olup olmadığı, okullaşma oranı ise eğitimin kalitesi hakkında bilgi vermemektedir (Klugman, Rodríguez ve Choi, 2011, s.11).

İGE'nin üç temel bileşenine eşit ağırlık verilmesi de eleştiriye konu olan bir başka husustur. Anand and Sen (1997) ve Haq (1995) bu bileşenlere farklı ağırlıklar verilmesine yönelik net bir gerekçe olmadığını ve ağırlıkların farklılaştırılmasının esas tartışmayı başlatacağını söylemesine rağmen bu konuda İGE'ye çeşitli eleştiriler yöneltilmiştir (Noorbakhsh, 1998, s.592). Ancak, bileşenler eşit ağırlıkta temsil edilse de sonucu etkileme kapasiteleri farklılaşmaktadır.

İGE için yapılan eleştirilerden bir diğeri de bu endeksin ülke içindeki gelişmişlik farklarını yansıtamaması olmuştur. UNDP bu eksikliği çeşitli ülkelerde bölge ve il düzeyinde İGE hesapları yaparak karşılamıştır. Diğer 
yandan çeşitli kurumlar ya da akademisyenler de kendi ülkeleri için bu tür çalışmalarda bulunmuş ve ülke içindeki gelişmişlik farklarını İGE formüllerini aynen ya da değiştirmek suretiyle hesaplayarak ortaya koymuştur (Foster, Lopez-Calva ve Szekely, 2005; Ismail ve Gosavi, 2010; Hazell, Gee ve Sharpe, 2012; Porter ve Purser, 2008; Silvayand ve Ferreira-Lopes, 2012).

İGE'ye yöneltilen eleştiriler yukarıda verilenlerle sınırlı değildir (Ravallion, 1997; Lind, 2004; Despotis, 2005; Seth, 2009). Tüm bu eleştirilere rağmen İGE başta hükümetler, uluslararası kuruluşlar ve bazı şirketler için önemli bir başvuru kaynağı olmaya devam etmektedir. Bunların bir kısmı İGE'nin temel mantığını koruyarak kendilerine özgü genişletilmiş endeksler üretmektedir.

\section{Türkiye'nin İnsani Gelişme Performansı}

Türkiye endeksin ilk üretildiği yıldan itibaren çalışmanın kapsamında yer almıştır. Ulus-altı düzeyde yapılan ilk endeks çalışmalarından birisi de 1992 yılındaki Türkiye Ulusal İnsani Gelişme Raporunda yer almıştır. 1992, 1995, 1996, 1997, 1998, 1999, 2001, 2004 ve 2008 yıllarında hazırlanan ulusal raporlarda hem Türkiye'nin endeks değeri diğer ülkeler ile karşılaştırılmış hem de il düzeyinde endeks değerleri üretilerek ülke içindeki insani gelişme düzeyleri ölçülmüştür (UNDP, 2018). Ayrıca bölge ve il düzeyinde yapılmış çalışmalar bulunmaktadır (Mıhçı, 2012; İnsani Gelişme Vakfı, 2017; Ünal, 2008).

Ülke sıralamaları ve endeks değerinden bağımsız olarak 1990-2016 yılları arasındaki İGR'ler incelendiğinde, İGE göstergeleri itibarıyla Türkiye'nin ilerleme sağladığı görülmektedir (Tablo 2). Göstergeler bazında incelendiğinde 1990-2016 döneminde sağlık ve gelir göstergelerinin iyileştiği görülmektedir. En fazla ilerleme kişi başı GSYİH göstergesinde kaydedilmiş olup, satın alma gücü paritesine göre hesaplanmış kişi başı gelir 1990 yılında 3.781 ABD dolarından 2016 yılında 18.705 ABD Dolarına yükselmiştir. Öte yandan aynı dönemde doğumda yaşam beklentisi 65 yıldan 75,5 yıla yükselmiştir. İGE'de kullanılan eğitim göstergeleri zaman içerisinde değişmiş ve ilk endeksten itibaren dört farklı gösterge kullanılmıştır. Yetişkin okuryazarlık oranı 1990 yılında yüzde 74'ten 2009'da 88,7'e yükselmiştir. Aynı şekilde farklı dönemlerde kullanılan bütünleşik, ortalama ve beklenen okullaşma oranlarında da artış yaşanmıştır. Özellikle beklenen okullaşma oranı 2010 yılında 11,8 yıl iken 2016 yılında 14,6 yıl olarak gerçekleşmiştir. 
Tablo 2. Göstergeler İtibarıyla Türkiye Verileri

\begin{tabular}{lccccc}
\hline Gösterge & $\mathbf{1 9 9 0}$ & $\mathbf{2 0 0 0}$ & $\mathbf{2 0 0 9}$ & $\mathbf{2 0 1 0}$ & $\mathbf{2 0 1 6}$ \\
\hline Doğumda yaşam beklentisi (yıl) & 65,0 & 69,3 & 71,7 & 72,2 & 75,5 \\
\hline Yetişkin okuryazarlık oranı (\%) & 74,0 & 84,0 & 88,7 & - & - \\
\hline Bütünleşik okullaşma oranı (\%) & - & 61,0 & 71,1 & - & - \\
\hline Ortalama okullaşma süresi (yıl) & - & - & - & 6,5 & 7,9 \\
\hline Beklenen okullaşma süresi (yıl) & - & - & - & 11,8 & 14,6 \\
\hline Kişi başı GSYİH (ABD doları) & 3.781 & 6.422 & 12.955 & 13.359 & 18.705 \\
\hline İGE & 0,751 & 0,732 & 0,806 & 0,679 & 0,767 \\
\hline
\end{tabular}

Kaynak: UNDP (2017b)

Şekil 1'de İGE ve alt endeksleri itibarıyla Türkiye ve diğer seçilmiş ülkelerin karşılaştırması yapılmaktadır. Karşılaştırmalarda 2015 yılı İGE raporunda kullanılan nüfus verileri ve G-20 üyeleri dikkate alınarak seçim yapılmıştır. Bu kapsamda, Türkiye ile karşılaştırılabilir olması bakımından nüfusu 50 milyondan fazla olan ülkeler (27 ülke) ile nüfusu ne olursa olsun G-20'ye üye ülkeler (Avrupa Birliği hariç) olmak üzere toplam 33 ülke karşılaştırmalarda dikkate alınmıştır. Bu ülkelerin İGE, sağlık, eğitim ve gelir alt endeksleri UNDP İnsani Gelişme Verileri Veritabanı kullanılarak 19902015 dönemi için yıllık olarak hesaplanmıştır (UNDP, 2017b). Endeks grafiklerinde, endeks değerinin büyüklüğüne göre bir renklendirme yapılmış ve Türkiye grafiklerde ayrı bir renk (yeşil) ve kalınlıkta gösterilmiştir. Bu gösterim şekli hem her bir endeks için Türkiye değerlerinin diğer ülkelerle karşılaştırabilmesini sağlamakta hem de Türkiye'nin yıllara göre İGE performansını ve alt endekslerin buna katkısını açıklamaktadır.

İGE endeksi incelendiğinde Türkiye'nin 25 yıllık performansı genel olarak karşılaştırılan ülkelerle paralellik arz etmektedir. Türkiye incelenen 33 ülke² arasında 1990 yılında 19. iken 2015 yılında 15. sıraya yükselmiştir. Bu süreç içerisinde Rusya, Arjantin ve Suudi Arabistan'ın aksine Türkiye yüksek insani gelişmişlik düzeyine erişememiş ve gelişmiş ülkeler ile arasındaki farkı kapatamamıştır. Bununla birlikte; Brezilya, Meksika, Filipinler, Güney Afrika, Kolombiya gibi ülkelerin gerisinde başladığı süreçte bu ülkelerin gelişmişlik düzeyini başlangıçta yakalamış sonra da geçmiştir. Aynı şekilde İGE endeksi itibarıyla gelişmiş ülkelerin birbirlerine yakınsadığı ancak gelişmekte olan ülkeler için açık bir yakınsama olmadı̆̆ı görülmektedir.

\footnotetext{
2 ABD, Almanya, Arjantin, Avusturalya, Bangladeş, Brezilya, Çin, Endonezya, Etiyopya, Filipinler, Fransa, Güney Afrika, Güney Kore, Hindistan, İngiltere, İran, İspanya, İtalya, Japonya, Kanada, Kolombiya, Kongo, Meksika, Misır, Myanmar, Nijerya, Rusya, Suudi Arabistan, Tanzanya, Tayland, Türkiye, Vietnam
} 


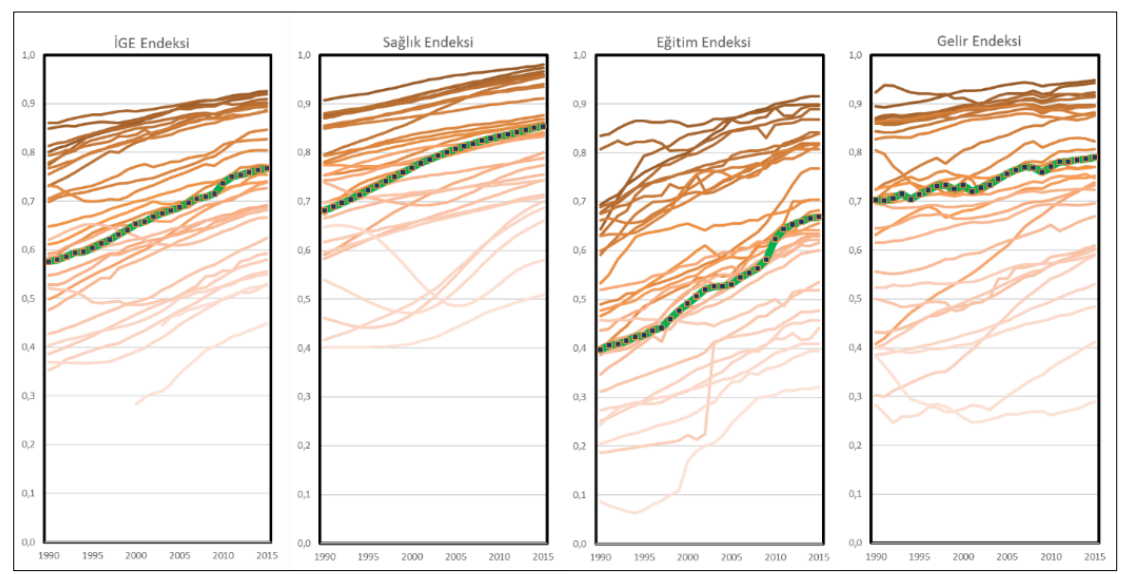

Şekil 1. İGE ve Alt Endeksler İtibarıyla Ülke Karşılaştırmaları

Kaynak: UNDP (2017b)

Sağlık endeksi incelendiğinde Türkiye'nin bu alanda oldukça önemli bir aşama kaydederek 22'nci sıradan 16'ncı sıraya yükseldiği ve yüksek gelişmişlik düzeyine eriştiği görülebilmektedir. Burada dikkat çekici husus Afrika kıtasını temsil eden ülkelerde AIDS vb. hastalıklara bağlı olarak sağlık endeksinde önemli kayıpların yaşandığı, bazı ülkelerin ise bu kayıpları telafi edebildiğidir. Güney Kore, Bangladeş ve Türkiye gösterdikleri performans ile ayrışmaktadır. Türkiye; Filipinler, Brezilya ve Mısır ile aynı düzeyde başladığı endekste bu ülkeleri geride bırakmış; Vietnam, Çin ve Arjantin'in endeks değerlerine yaklaşmıştır. Diğer bir ifadeyle Türkiye gelişmiş ülkelere yakınsamış, gelişmekte olan ülkelerin ortalamasından daha yüksek bir performans göstermiştir. Genel olarak sağlık endeksi değerinin diğer endekslere göre yüksek bir değere sahip olduğu da şekillerden anlaşlmaktadır.

Türkiye karşılaştırma yapılan ülkeler arasında 21. sıradan 17. sıraya kadar yükselerek eğitim endeksinde de önemli bir ilerleme kaydetmiştir. Buna rağmen Güney Afrika, İran ve Suudi Arabistan'ın gerisinde kalmıştır. Eğitim endeksinde farklılıkların daha fazla olduğu ve yüksek gelişmişlik düzeyindeki ülkelerin gelişmekte olan ülkelerden açıç̧a ayrıştığ 1 görülmektedir. Türkiye bu endekste gelişmiş ülkelere yakınsamasına rağmen henüz yüksek gelişmişlik düzeyinin çok gerisinde kalmaktadır.

Gelir endeksi grafiğinde Türkiye'nin yatay bir seyir izlediği görülmekte olup, sıralamada 1990 yılındaki 16.'lıktan günümüzde 14.'lüğe yükseldiği görülmektedir. Şekilde; Çin, Myanmar ve Güney Kore dışındaki ülkelerin 
birbirine yakın bir performans izlediği ve genellikle seçilen ülkeler arasında gelir farklılıklarında bir yakınsamanın olmadığı görülmektedir.

Tüm endeksler birlikte değerlendirildiğinde yüksek insani gelişmişlik düzeyine sahip ülkelerin gelişmekte olan ülkelerden ayrıştığı görülmektedir. Türkiye'nin tüm endekslerde gelişmekte olan ülkeler arasında yerini aldığı ve özelikle sağlık endeksinde bu ülkelere öncülük ettiği görülebilmektedir. Eğitim endeksi ise alt endeksler arasında iyileşmeye en çok ihtiyaç duyulan alan olmuştur.

\section{İl Bazında İnsani Gelişme Endeksi ve Alt Endeksler}

Bu çalışmada ülkelerin insani gelişmişliklerinin karşılaştırılması amacıyla UNDP tarafından yayımlanan İGE, Türkiye'deki 81 il için 2014 verileriyle üretilmiştir. Çalışmaya ilişkin doğumda beklenen yaşam süresi verisi Türkiye İstatistik Kurumu'ndan (TÜİK) temin edilmiştir. Beklenen ve ortalama okullaşma yılı verisinin elde edilebilmesi için Milli Eğitim Bakanlığı (MEB), Yükseköğretim Kurulu Başkanlığı (YÖK) ve TÜİ'ten alınan veriler yazarlar tarafından hesaplanmıştır. Kişibaşı GSYİH verisi de TÜİ'ten alınmıştır. Çalışmada 2014 yılı verilerinin kullanılmasının nedeni TÜIKK tarafından yayımlanan en güncel il bazında GSYİH verisinin 2014 yılına ait olmasıdır. 2016 yılında TÜIK tarafından 2004-2014 yıllarına ait yayımlanan il bazında gelir verisinden sonra bu seride herhangi yeni bir güncelleme yapılmamıştır. Dolayısıyla bu çalışma önceki yıllarda il bazında gelir verisinin çeşitli tahmin yöntemleri kullanılarak hesaplanan çalışmalardan, TÜİK verilerinin kullanılmasıyla yönüyle ayrışmaktadır.

Söz konusu verilere ilişkin özet tablo Ek-2' de yer almaktadır. Bu çalışma ile iller bazında İGE'nin yanı sıra üç alt endekse ait değerler de sunulmaktadır. İl bazında İGE ve alt endekslerin sunulmasıyla iller arasındaki farklar ortaya konulmuş, güçlü olunan ve iyileştirme ihtiyacı bulunan alanlar belirtilmiştir. Alt endekslerin ortaya konulması ile il düzeyinde insani gelişmişlik farklılıkları daha iyi analiz edilebilmiştir. Başta politika yapıcılar olmak üzere akademisyenler, sivil toplum kuruluşları ve ilgili diğer tarafların yapacağı analitik çalışmalara önemli bir girdi sağlanacaktır.

\section{İlerin İnsani Gelişme Endeksi (İGE)}

UNDP tarafından 2014 yılında yayımlanan metodolojiye göre hazırlanan illerin İGE değerleri, sıralaması ve insani gelişmişlik kategorisi Ek-3'te yer 
alan tabloda sunulmaktadır. Tabloya göre yüksek insani gelişmişlik grubunda yer alan Türkiye'de, sadece Ankara çok yüksek insani gelişmişlik grubunda yer almaktadır. Ankara sağlık endeksinde 10. sırada, eğitim endeksinde 1. sırada ve gelir endeksinde ise 3. sırada yer almaktadır. Türkiye'nin büyük bir çoğunluğu (65 il) yüksek insani gelişmişlik kategorisinde yer almaktadır. Geriye kalan 15 il ise orta yüksek insani gelişmişliğe sahiptir. Kilis ili hariç orta yüksek insani gelişmişliğe sahip 14 il Güneydoğu ve Doğu Anadolu bölgesinde yer almaktadır. Türkiye'de düşük insani gelişmişliğe sahip il yer almamaktadır (Şekil 2).

Yedi ilin endeks değerinin bir üst kategoriye ait eşik değere çok yakın olmasından dolayı yakın zamanda bir basamak atlayarak çok yüksek insani gelişmişlik kategorisine yükselebileceği tahmin edilmektedir. Aynı çerçevede, orta yüksek insani gelişmişliğe sahip 6 ilin de kısa zaman içerisinde yüksek insani gelişmişlik sınıfına yükselmesi olasıdır.

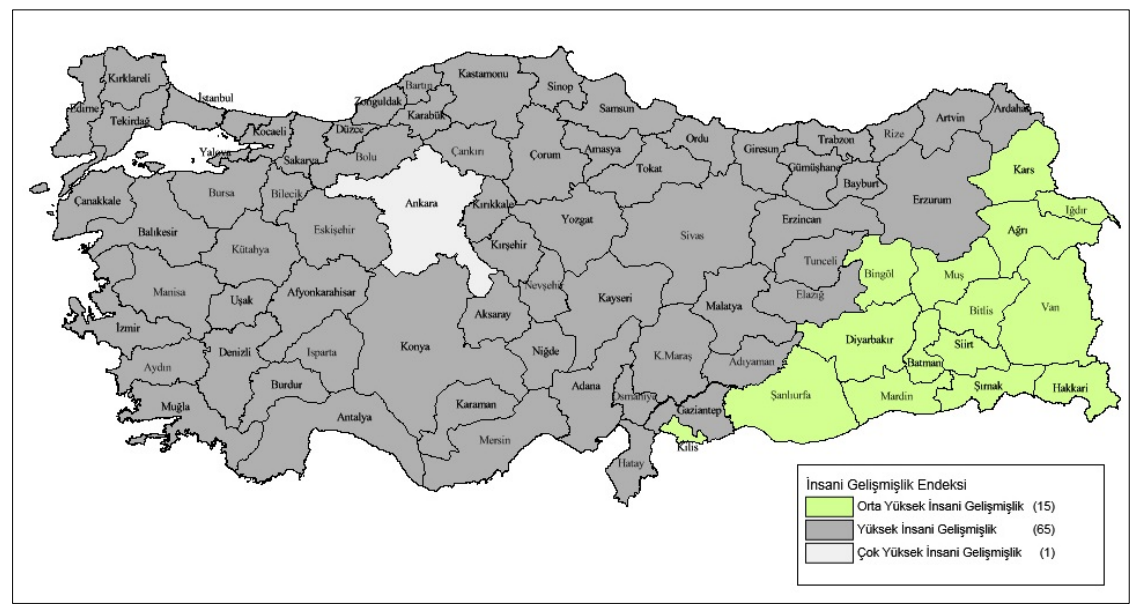

Şekil 2. İller İtibarıyla İGE Kategorileri

Kaynak: Yazarlar tarafından hazırlanmıştır.

\section{Illerin Sağlık Endeksi}

İGE'nin ilk bileşeni olan sağlık endeksi doğumda beklenen yaşam süresi değişkenine göre hesaplanmaktadır (UNDP, 2016b). BM, hiçbir ülkenin beklenen yaşam süresini 20 yıldan düşük olamayacağı varsayımından (Maddison, 2010; Oeppen ve Vaupel, 2002; Riley, 2005) yararlanarak minimum yaşam süresini belirlemiştir.

Ek-2' de belirtilen formüle dayanılarak oluşturulan İGE sağlık endeks değeri ve illerin sıralaması Ek-4'te sunulmaktadır. Buna göre Türkiye'nin tüm 
illerinin oldukça yüksek sağlık endeks değerlerine sahip olduğu görülmektedir. İGE sağlık endeksi bazında tüm iller 0,80 ve daha yüksek değere sahip olduğu için çok yüksek insani gelişmişlik sınıfında yer almaktadır. İGE sağlık endeksinde Muğla, Tunceli ve Mardin ilk üç sırayı almıştır. Bununla birlikte, Karadeniz Bölgesi illerinin üst sıralarda yer aldığı görülmektedir. Afyonkarahisar ve Kütahya'nın görece dezavantajlı konumu (75. ve 76.) dikkat çekicidir.

Tüm illerin sağlık endeks değerleri yüksek insani gelişmişlik kategorisinde yer aldığ dır. Bu sebeple, illerin sağlık endeks değerleri doğal kırılımlarına ${ }^{3}$ göre dört kategoride ${ }^{4}$ belirtilerek iller arasındaki sağlık endeksi bakımından farklılıklar Şekil 3'te ortaya konulmaya çalışılmıştır.

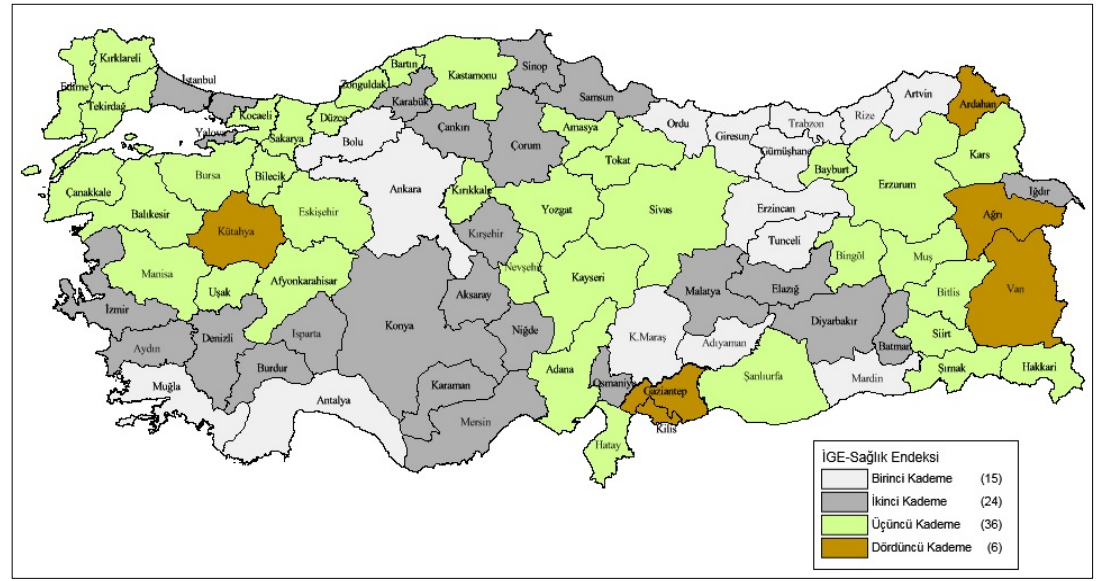

Şekil 3. İller İtibarıyla Sağlık Endeksi Kategorileri

Kaynak: Yazarlar tarafından hazırlanmıştır.

\section{Illerin Ĕ̆itim Endeksi}

İGE'nin ikinci bileşeni olan eğitim endeksi ortalama okullaşma yılı ve beklenen ortalama okullaşma yılı değişkenleri ile hesaplanmaktadır. Diğer bir deyişle, eğitim endeksi iki alt bileşenin aritmetik ortalamasıdır. Söz konusu

\footnotetext{
${ }^{3}$ Her sınıf diğer sınıfa göre daha yakın değerlere sahip olup her sınıfın ortalaması mümkün olduğu kadar o sınıfta yer alan değerlere yakındır. Söz konusu kırılım değerleri illerin ortalama değerlerinin oluşturulabilecek alternatif grup ortalamalarından sapmaları doğrultusunda tespit edilmektedir. Bir sınıfın minimum değerinin sonraki sınıf değerleriyle arasında önemli bir fark yani bir kırılım değeri bulunmaktadır. Söz konusu kademelenme çalışmasındaki kırılım değerleri Coğrafi Bilgi Sistemleri yazılımı tarafından haritalama esnasında otomatik olarak belirlenmiştir.

${ }^{4}$ Birinci kademe en yüksek gelişmişliği, dördüncü kademe ise görece daha az gelişmişliği göstermektedir.
} 
alt bileşenlerin hesaplama yöntemi Ek-2'de detaylı bir şekilde verilmektedir. BM'nin 2025 yılına kadarki projeksiyonuna göre maksimum ortalama okullaşma süresi 15 yıl olarak tahmin edilmektedir. Bu sebeple BM, maksimum ortalama okullaşma süresini 15 yıl olarak kabul etmektedir. Ortalama okullaşma yılı Ek-2' deki formüle göre hesaplanmaktadır (UNDP, 2016b; Rigotti vd., 2013; Yeşilyurt, Karadeniz, Gülel, Çağlar ve Kangall1-Uyar, 2016; UNESCO, 2013).

Ek-5'te yer alan tabloda illerin beklenen ortalama okullaşma yılı ve ortalama okullaşma yılı değerleri gösterilmektedir. Söz konusu tabloya göre Türkiye'nin ortalama okullaşma yılının 8 yıla yaklaştı̆̆ı görülmektedir. Ortalama okullaşma yılının en yüksek olduğu üç il sırasıyla Ankara, Eskişehir ve İzmir illeridir. Ortalama okullaşma yılı açısından Doğu ve Güneydoğu Anadolu Bölgesi illeri son sıralarda yer almaktadır. Söz konusu bölgelerde en üst siraya sahip olan 22. siradaki Tunceli ilinin konumu bölgesinde yer alan iller dikkate alındığında oldukça dikkat çekicidir. Ayrıca 6. sırada ortalama okullaşma yılına sahip olan Artvin de öne çıkan diğer bir ildir.

Beklenen okullaşma yılı değerleri bakımından ilk sıralarda çoğunlukla Karadeniz Bölgesi illeri yer almaktadır. Ortalama okullaşma yılı çok yüksek olmayan illerde beklenen okullaşma yılının yüksek olması okul terk oranları ve göç verileri ile açılanabilir (Yeşilyurt vd., 2016, s.7). Bu değişken aç1sından yaklaşık 15 yıl ile İstanbul 51. sırada bulunmaktadır. Beklenen okullaşma yılı açısından Doğu ve Güneydoğu Anadolu Bölgesi illeri son sıralarda yer almaktadır.

İGE kategorilerinin belirlenmesinde kullanılan endeks değerleri eşik değerlerine göre İGE eğitim endeks değeri illere göre sınıflandırılarak Şekil 4 'te gösterilmektedir. Buna göre İGE eğitim endeks değeri açısından 6 il düşük insani gelişmişlik sınıfında yer almaktadır. Türkiye'nin büyük bir kısmı eğitim endeks değerleri açısından orta yüksek insani gelişmişlik sınıfında bulunmakla birlikte 17 il eğitim endeksine göre yüksek insani gelişmişlik sınıfına girmektedir. Türkiye'de hiçbir il İGE eğitim endeksi açısından çok yüksek insani gelişmişlik sınıfına girememektedir. Bununla birlikte, eğitim endeksine göre orta yüksek insani gelişmişlik sınıfında yer alan 11 ilin endeks değerinin bir üst kategori eşik değerine çok yakın olması ve eğitim alanındaki olumlu gelişmelere bağlı olarak yakın zamanda bu endekse göre bir üst sınıfta yer alması olasıdır. 


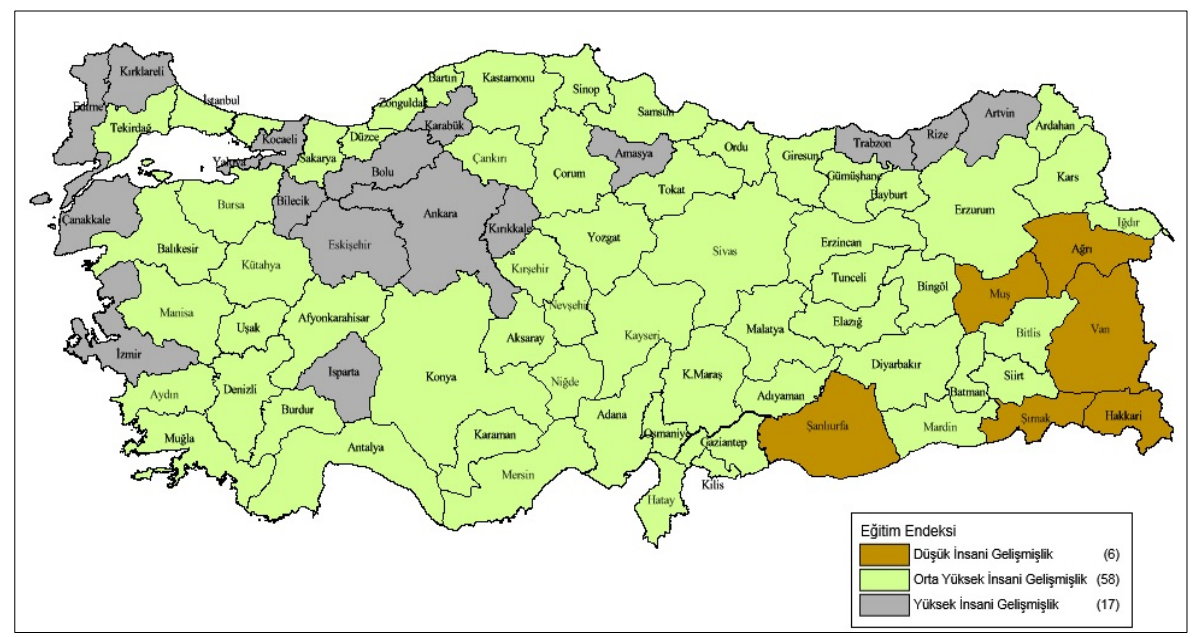

Şekil 4. İller İtibarıyla Eğitim Endeksi Kategorileri

Kaynak: Yazarlar tarafından hazırlanmıştır.

Ortalama okullaşma yılı ve beklenen ortalama okullaşma yılına göre oluşturulan IGGE eğitim endeks değeri ve illerin sıralaması Ek-6'da yer alan tabloda gösterilmektedir.

\section{İllerin Gelir Endeksi}

İGE'nin son bileşeni olan gelir endeksinde kişi başı gelir değişkeni tek değişken olarak dikkate alınmaktadır. Söz konusu endeks değeri hesaplamalarında farklılıkları azaltmak adına logaritmik değerler kullanılmaktadır. Diğer bir deyişle, daha düşük kişi başı gelire sahip illerin görece ağırlığını artırmak yüksek olanların ise gelir durumundan kaynaklanan ağırlık durumunu azaltmak amacıyla değerlerin logaritmik formu kullanılmaktadır. Gelir endeksi Ek-2' deki gibi hesaplanmaktadır (UNDP, 2016b). BM, Kahneman ve Deaton (2010)'un belirttiği kişi başı 75.000 ABD Dolarının üzerinde insani gelişmişlik ve refah bağlamında herhangi bir kazanım olmayacağından yola çıkarak maksimum kişi başı gelir rakamını belirlemiştir. Sadece dört ülke (Kuveyt, Lihtenştayn, Katar ve Singapur) 75.000 ABD Dolarlık kişi başı gelir seviyesi üzerinde yer almaktadır. BM, dikkat çekici bir biçimde, minimum kişi başı gelir tutarını parasal karşılığı olmayan üretimleri de hesaba katarak 100 ABD Doları olarak belirlemiştir.

İGE'nin belirlenmesinde kullanılan endeks değerleri eşik değerlerine göre gelir endeks değeri illere göre sınıflandırılarak Şekil 5'te gösterilmektedir. Buna göre İGE gelir endeks değeri açısından sadece 1 il (İstanbul) çok 
yüksek insani gelişmişlik sınıfında yer almaktadır. Türkiye'nin büyük bir kısmı gelir endeks değerleri açısından orta yüksek insani gelişmişlik sınıfında bulunmakta iken 22 il yüksek insani gelişmişlik sınıfına girmektedir. Türkiye'de hiçbir il İGE gelir endeksi açısından düşük insani gelişmişlik s1nıfında yer almamaktadır.

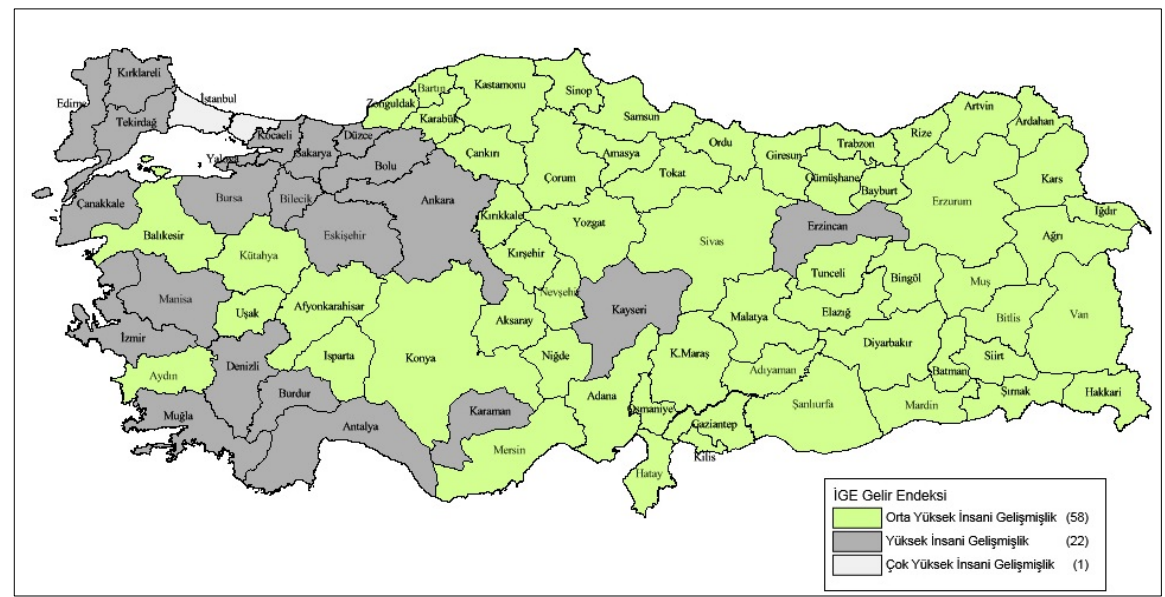

Şekil 5. İller İtibarıla Gelir Endeksi Kategorileri

Kaynak: Yazarlar tarafindan hazırlanmıştır.

İllerin gelir endeks değerleri ile sıralamaları Ek-7'de sunulmaktadır. Bununla birlikte, kişibaşı GSYH verisi ortalama bir değeri göstermektedir. Söz konusu veri ülke ve illerin oldukça farklı karakteristikleri ve kendi içerisindeki farklılıkların göstermemektedir. Bu sebeple, kişibaşı GSYH verisinin yanında gelir dağılımın da endekse dahil edilmesinin insani gelişmişliği daha iyi açıklayabileceği değerlendirilmektedir.

\section{ÍGE ile Alt Endekslere Ait Tanımlayıcı İstatistikler}

İllerin İGE ve alt endekslere ait tanımlayıcı istatistikler incelendiğinde Türkiye'de İGE değerlerinin 0,617 ile 0,809 aralığında olduğu, eğitim ve gelir alt endekslerine göre daha az değişkenlik gösterdiği belirtilebilir. Eğitim endeks değerlerinin diğer endeks değerlerine göre görece daha düşük seviyede bulunduğu ve daha fazla değişkenlik gösterdiği göze çarpmaktadır. Diğer bir deyişle, iller arasında eğitim endeks değeri bakımından daha büyük bir dalgalanma mevcuttur.

Sağlık endeks değerlerinin ise diğer endekslere göre oldukça yüksek değerler aldığı ve en az değişkenliğe sahip alt endeks olduğu ifade edilebilir. 
Endeks değerlerinin çarpıklık ve basıklık katsayılarına bakıldığında gelir endeksi hariç diğer endekslerin negatif çarpıklık değeri aldığı ve bu nedenle dağılımların normal dağılıma göre sağa çarpık olduğu belirtilebilir (Tablo 3). Yani endeks değerleri ortalamanın üstündeki değerlerde yoğunlaşmıştır. Basıklık katsayısı açısından ise gelir endeksi hariç diğer endekslerin pozitif değer aldığı ve verilerin normal dağılıma göre daha dik (homojen) olduğu söylenebilir.

Tablo 3. İGE ve Alt Endekslere İlişkin Tanımlayıcı İstatistikler

\begin{tabular}{lcccccc}
\hline Endeks & Minimum & Maksimum & Ortalama & Varyans & Çarpıklık $^{5}$ & Basıklık $^{6}$ \\
\hline İGE & 0,617 & 0,809 & 0,734 & 0,002 & $-0,795$ & 0,232 \\
\hline Sağlık Endeksi & 0,846 & 0,931 & 0,894 & 0,000 & $-0,083$ & 0,915 \\
\hline Eğitim Endeksi & 0,497 & 0,750 & 0,658 & 0,004 & $-1,056$ & 0,313 \\
\hline Gelir Endeksi & 0,553 & 0,800 & 0,675 & 0,003 & 0,129 & $-0,077$ \\
\hline
\end{tabular}

Kaynak: Yazarlar tarafından hazırlanmıştır.

\section{ÍGE İle Sağllk Endeksi Arasındaki İlişki}

İGE ve sağlık endeksi arasında istatistiksel olarak anlamlı bir ilişki olup olmadığı aşağıdaki hipotezler ile test edilmektedir. Söz konusu hipotezler yardımıyla endekslerin birbirini etkileyip etkilemediği, iki endeks arasındaki ilişki istatistiksel olarak anlamlıysa ilişkilerinin yönü ve gücü analiz edilmiştir.

Ho : İnsani gelişmişlik endeksi ile sağlık endeksi arasında ilişki yoktur.

Hs : İnsani gelişmişlik endeksi ile sağlık endeksi arasında ilişki vardır.

Bu çerçevede, İGE ile sağlık endeksi ${ }^{7}$ arasındaki ilişki istatistiki 0,003 anlamllık düzeyinde reddedilmektedir. Alternatif hipotezde sunulan insani gelişmişlik endeksi ile sağlık endeksi arasında istatistiksel bir ilişki olduğu savı hipotez testi neticesinde ortaya çıarılmıştır. İGE ile sağlık endeksi ara-

\footnotetext{
${ }^{5}$ Çarpıklık, verilerin simetriden ayrılması anlamına gelmektedir. Normal dağılımda çarpıklık katsayısı 0 olarak varsayılır. Bir dağılımın çarpıklık katsayısı negatif ise dağılım sağa, pozitif ise sola çarpıktır.

${ }^{6}$ Basıklık, verilerin normal dağılım etrafında yoğunlaşma derecesini göstermektedir. Basıklık katsayısı normal dağılımda 0'dır. Pozitif basıklık değerleri normal dağılıma göre dikliği, negatif değerler ise dağılımın normal dağılıma göre basıklığı gösterir.

7 İGE'nin normal dağılıma sahip olup olmadığı test edildiğinde hipotez 0,003 anlamlılık düzeyinde reddedilmektedir. Sağlık endeksine ait hipotez ise 0,064 anlamlılık düzeyine sahip olup bunun üzerindeki değerlerde reddedilmektedir. İGE ile sağlık endeksi arasındaki ilişki parametrik olmayan testlerden Spearman sıra korelasyon katsayısı ile ölçülmüştür.
} 
sında yaklaşık \% 33'lük zayıf bir ilişki olduğu \% 1 yanılma payı ile söylenebilir. Söz konusu zayıf ilişkiden dolayı sağlık endeksinin İGE üzerinde çok kısmi bir etki oluşturacağı göz önünde bulundurulmalıdır.

Sağlık endeksinin İGE'nin bir alt endeksi olmasından dolayı söz konusu ilişkinin derecesi düşündürücüdür. Bu noktada, BM'nin sağlık endeksi başlığında bebek ölüm oranı, temiz suya ve/veya sağlığa erişim vb. yeni değişkenleri de ilave ederek yeni bir birleşik sağlık endeksini oluşturması kritik öneme sahiptir. İGE sağlik endeksinde kullanılan mevcut değişkene ilişkin ilave verilerin de eklendiği yeni bir sağlık endeksi oluşturulmasının çalışmasının güvenilirliğini artıracağı söylenebilir.

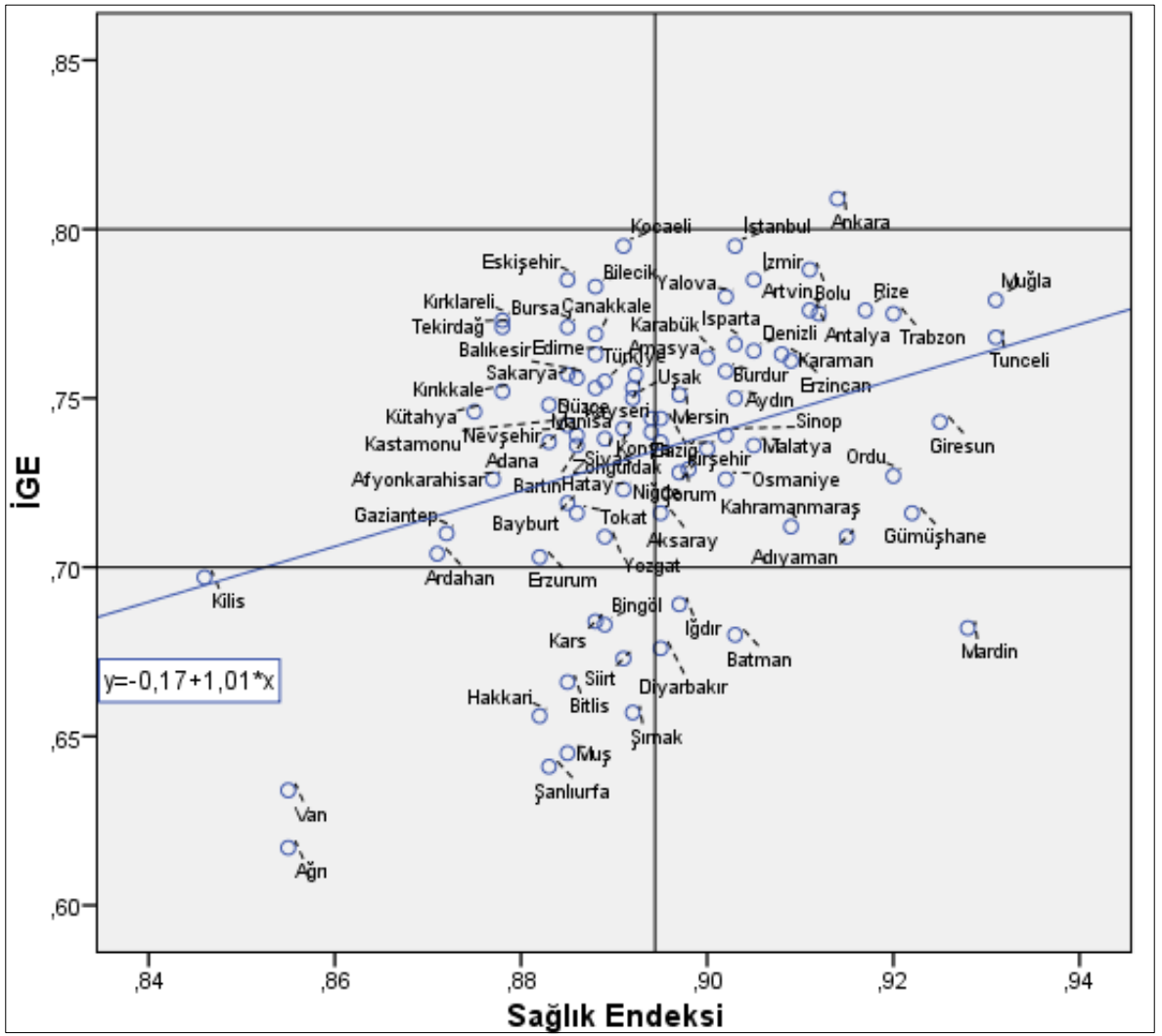

Şekil 6. İGE ve Sağlık Endeksi Saçılım Grafiği

Kaynak: Yazarlar tarafından hazırlanmıştır.

Ayrıca, Şekil 6'daki saçılım grafiğinde belirtilen regresyon denkleminde bağımsız değişken sağlık endeksinin bağımlı değişken İGE'yi yüzde 16'lık 
düşük bir oranda açıklaması da sağlık endeksinin İGE için yetersiz kaldığı çıkarımını teyit etmektedir ${ }^{8}$. İlgili şekilde tüm illerin sağlık endeks değeri en üst sınıfta yer aldığı için Türkiye sağlık endeks değeri ortalama değer olarak alınmıştır. İGE sınıflandırması da BM'nin standart sınıflama değerleri 0,80 ve 0,70 eşik endeks değerlerine göre yapılmıştır. Grafiğe göre Ağrı, Van ve Kilis'in hem İGE hem de sağlık endeks değerinin düşük, Ankara, İzmir, İstanbul ve Muğla'nın ise her iki endekste de yüksek değerler aldığı belirtilebilir. Ayrıca, Mardin yüksek bir sağlık endeks değerine sahipken İGE endeks değeri oldukça düşük çıkmıştır. Oluşturulan tek değişkenli regresyon sonuçlarının regresyon denklemine ilave değişkenler eklendiği zaman değişebileceği hususu göz önünde bulundurulmalıdır.

\section{İGE İle Eğitim Endeksi Arasındaki İlişki}

İGE ve eğitim endeksi arasında istatistiksel bir ilişkinin varlığı aşağıdaki hipotezler yardımıyla araştırılmaktadır. Söz konusu hipotezlerle endekslerin birbirlerine etki edip etmedikleri ile ilişkilerinin yönü ve gücü analiz edilmektedir.

Ho : İnsani gelişmişlik endeksi ile eğitim endeksi arasında ilişki yoktur.

Hs : İnsani gelişmişlik endeksi ile eğitim endeksi arasında ilişki vardır.

Bu çerçevede, İGE ile eğitim endeksi ${ }^{9}$ arasındaki ilişkiye ait sıfır hipotezi 0,000 istatistiki anlamlılık düzeyinde reddedilmektedir. Alternatif hipotezde ifade edildiği üzere insani gelişmişlik endeksi ile eğitim endeksi arasında istatistiksel bir ilişki olduğu belirtilebilir. İlişkinin derecesine bakıld1ğında, İGE ile eğitim endeksi arasında \% 94,4'lük çok kuvvetli bir ilişki olduğu \% 1 yanılma payı ile söylenebilir. Bu ilişki ışığında eğitim endeksinin İGE'nin oluşturulmasında çok büyük bir ağırlığa sahip olduğu açık bir şekilde söylenebilir.

Ayrıca, söz konusu ilişki Şekil 7'deki saçılım grafiği ile gösterildiğinde oluşturulan regresyon denkleminin $\mathrm{R}^{2}$ belirtme katsayı değeri de mevcut durumu teyit etmektedir. İlgili regresyon denklemi istatistiki olarak anlamlıdır. Ayrıca, denklemdeki bağımsız değişken eğitim endeksindeki 1 birim

\footnotetext{
${ }^{8}$ Regresyon analizine göre regresyon denklemi ve sağlık endeksi istatistiki olarak anlamlıdır.

${ }^{9}$ Eğitim endeksinin normal dağılıma sahip olup olmadı̆̆ test edildiğinde hipotez 0,000 anlaml1lık düzeyinde reddedilmektedir. Bu kapsamda, İGE ile eğitim endeksi arasındaki ilişki parametrik olmayan testlerden Spearman sıra korelasyon katsayısı ile ölçülmüştür.
} 
değişimin bağımlı İGE değişkeninde aynı yönde 0,65 birim değişikliğe sebep olduğu belirtilebilir ${ }^{10}$. İlgili şekilde iller üç farklı sınıfta İGE ve eğitim endeks değerine sahip olduğu için yatay ve dikey eksenlere ikişer eşik değer konulmuştur. Grafiğe göre illerin eğitim yönünden gelişmişliği ile insani gelişmişliği büyük ölçüde paralel gitmektedir. Önceki şekilde olduğu gibi Ağrı ve Van'ın durumu aynı şekilde kalmıştır. Eğitim endeksinde Ankara, Eskişehir ve Artvin illeri dikkat çekmektedir.

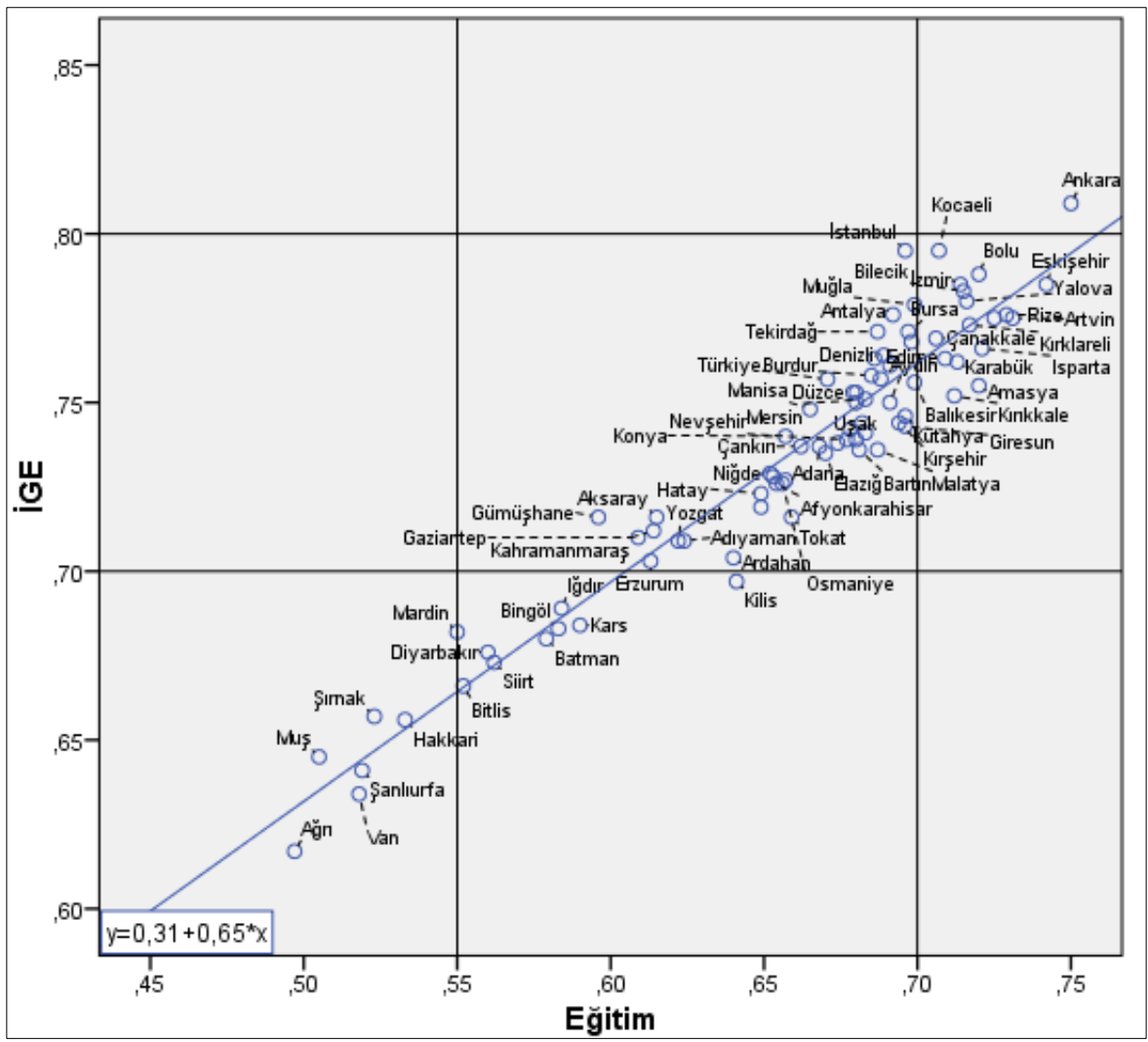

Şekil 7. İGE ve Eğitim Endeksi Saçılım Grafiği

Kaynak: Yazarlar tarafından hazırlanmıştır.

${ }^{10}$ Oluşturulan tek değişkenli regresyon sonuçlarının regresyon denklemine ilave değişkenler eklendiği zaman değişebileceği hususu göz önünde bulundurulmalıdır. 


\section{İGE İle Gelir Endeksi Arasındaki İlişki}

İGE ve gelir endeksi arasındaki ilişki istatistiksel olarak aşağıdaki hipotez testi ile araştırıldığında İGE ile gelir endeksi ${ }^{11}$ arasındaki ilişkiye ait sıfır hipotezi 0,000 anlamlılık düzeyinde reddedilmektedir.

Ho : İnsani gelişmişlik endeksi ile gelir endeksi arasında ilişki yoktur.

Hs : İnsani gelişmişlik endeksi ile gelir endeksi arasında ilişki vardır.

Bu neticeye göre ilgili alternatif hipotezin kabul edilmesiyle ikinci adım olarak ilişkinin derecesi incelenmelidir. İGE ile gelir endeksi arasında \% 93,1'lik çok kuvvetli istatistiksel bir ilişki olduğu \% 1 yanılma payı ile söylenebilir. Gelir endeksi İGE'nin bir alt endeksi olmasından dolayı söz konusu ilişkinin derecesinin olağan olduğu değerlendirilmiştir. İGE ile gelir arasındaki ilişki Şekil 8'deki saçlım grafiği ile gösterildiğinde oluşturulan regresyon denkleminin $\mathrm{R}^{2}$ belirtme katsayı değeri \% 87 çımıştır. Diğer bir deyişle kurulan regresyon denklemindeki bağımsız gelir endeks değerleri bağımlı İGE değerini çok yüksek bir oranda açıklayabilmektedir. Regresyon denklemi ve gelir endeksi katsayısı istatistiki olarak anlamlıdır ${ }^{12}$. Grafiğe göre, gelir endeks değeri bir birim arttığında İGE de 0,75 birim artmaktadır. Kocaeli ve İstanbul'un gelir endeks değeriyle Ağrı, Van ve Şanlıurfa'nın değerleri uç değerleri oluşturmaktadır.

\footnotetext{
${ }^{11}$ Gelir endeksinin normal dağılıma sahip olup olmadığı test edildiğinde hipotez 0,200 anlamlılık düzeyinde kabul edilmektedir. Ancak İGE normal dağılıma sahip olmadığı için İGE ile gelir endeksi arasındaki ilişki parametrik olmayan testlerden Spearman sıra korelasyon katsayısı ile ölçülmüştür.

${ }^{12}$ Oluş̧turulan tek değişkenli regresyon sonuçlarının regresyon denklemine ilave değişkenler eklendiği zaman değişebileceği hususu göz önünde bulundurulmalıdır.
} 


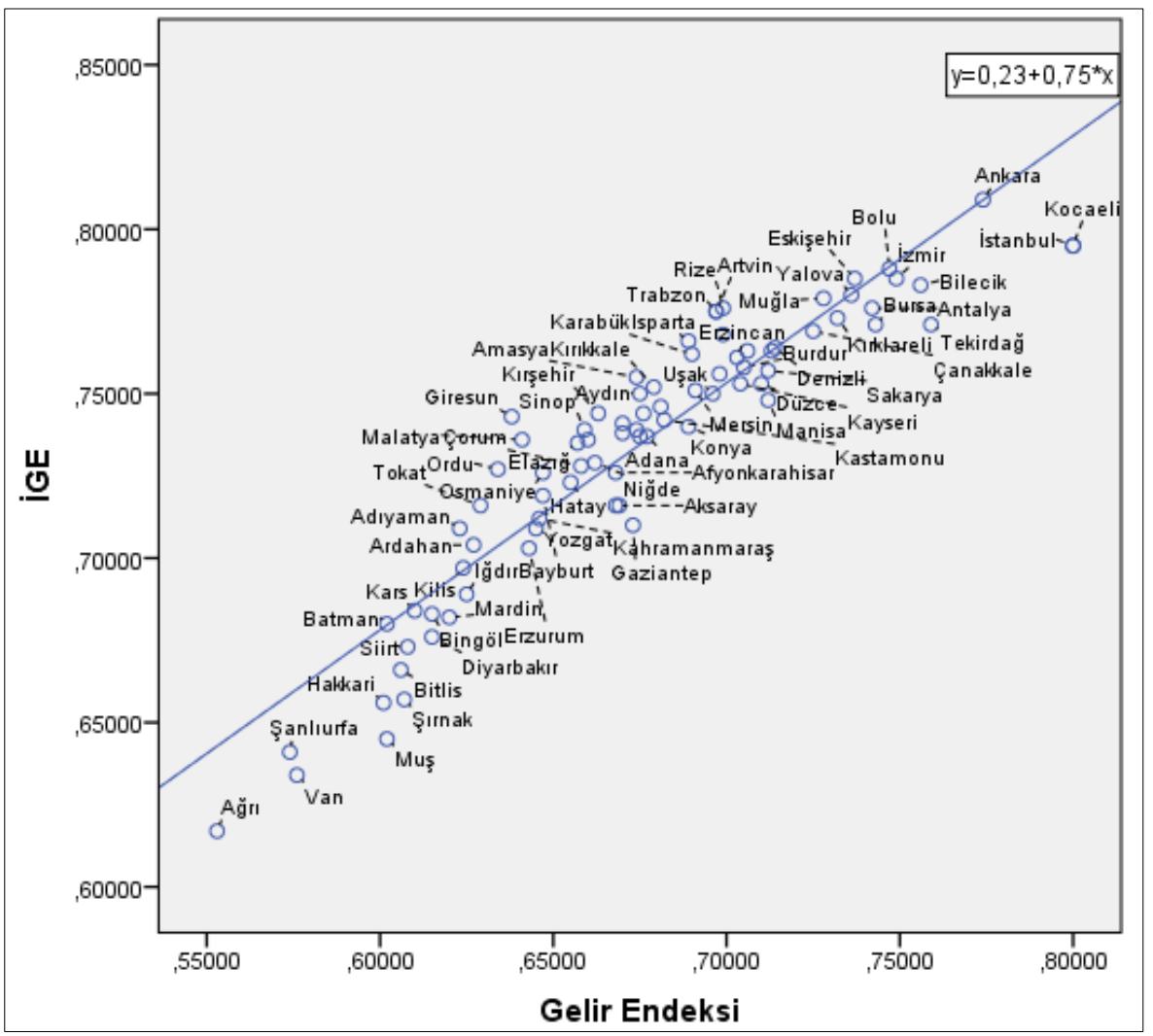

Şekil 8. İGE ve Gelir Endeksi Saçılım Grafiği

Kaynak: Yazarlar tarafından hazırlanmıştır.

İGE 2014 hesaplamalarını içeren bu çalışmanın sonuçları benzer çalışmalar ile karşılaştırma adına TEPAV tarafından yapılan İGE 2013 (Özpınar ve Koyuncu, 2016) ve Kalkınma Bakanlığı tarafından yapılan SEGE 2011 (Kalkınma Bakanlığı, 2013) çalışmaları kullanılmış olup, karşılaştırma tabloları Ek-8'de sunulmuştur. Buna göre İGE 2014 ve İGE 2013 arasında iller itibarıyla farklılıkların sınırlı düzeyde olduğu görülmüştür. Sekiz ilin endeks s1rası önceki yılla aynı iken 61 ilin sırası 10'dan daha fazla değişmemiştir. Zonguldak, Kırıkkale ve Kilis en çok ilerleme kaydeden iller iken; İstanbul, Düzce ve Tunceli sıralamada en fazla gerileyen iller olmuştur. Bu iki çalışma arasında sıralamada ortaya çıkan farklılıklar 2014 yılında güncellenen il bazındaki gelir verisi ve İGE hesaplarında kullanılan eğitim göstergelerindeki değişiklikle açıklanabilir. 
İGE 2014 ile SEGE 2011 arasındaki farklılıklar incelendiğinde ise 10 ilin sıralamasının en fazla 1 sıra, 60 ilin sırasının ise 10'dan daha az farklılaştığ görülmektedir. İGE 2014'te Gaziantep, Adana ve Konya SEGE'ye kıyasla çok daha üst sıralarda iken Rize, Artvin ve Tunceli SEGE'ye oranla çok daha alt siralarda yer almaktadır. Bu farklılıklar ise SEGE'de olup İGE'de yer verilmeyen eğitim ve sağlık dışındaki temel sosyo-ekonomik göstergeler ile izah edilebilir. Son olarak, İGE 2014 ile SEGE 2011 arasındaki istatistiki ilişki incelendiğinde ise iki endeks arasında yüzde 89'luk kuvvetli pozitif bir ilişki olduğu yüzde 99 güven düzeyinde belirtilebilmektedir.

\section{Sonuç}

İGE, yöneltilen tüm eleştirilere rağmen yola çıkarken koyduğu ilke ve hedefleri başarılı bir şekilde gerçekleştirebilmiştir. Bu nedenle, uluslararası literatürün en uzun soluklu endeks çalışmalarından birisi haline gelmiştir. Ülkelerin veri altyapısı ve mevcudiyeti dikkate alındığında, İGE kapsayıc1lığı, sürdürülebilirliği ve özetleyiciliği bakımından literatürün en önemli çalışmalarından birisidir. Bu sebeplerden dolayı, İGE politika yapıcılar, akademisyenler ve sivil toplumun sıklıkla başvurduğu başlıca kaynaklardandır. Özellikle gelişmekte olan ülkeler politika analizlerinde güçlü ve zayıf oldukları İGE alanlarına yoğunlaşmakta, ülkelerinin insani gelişmişlik sıralamasını iyileştirmeyi hedeflemektedirler. İGE'nin basit ve etkin yapısı ülkeleri olduğu gibi bölgeleri ve illeri de birbirleriyle karşılaştırmayı kolaylaştırmaktadır. Türkiye ülke içi karşılaştırmanın yapıldığı ilk ülkelerden biri olmuştur. 1993 yılından itibaren doğrudan BM'nin ulusal raporları ya da çeşitli akademik ya da kurumsal yayınlar ile il bazında İGE hesapları yapılagelmiştir. İGE endeksini oluşturan göstergelerden eğitim ve sağlık göstergeleri il bazında düzenli aralıklarla yayımlanmasına rağmen gelir verisi belirli bir takvim çerçevesinde yayımlanmamaktadır. Bununla birlikte, söz konusu veriler kapsam ve içerik açısından yeterlidir.

İller bazındaki çalışmanın sonucunda, İGE ve alt endekslerde ilk ve son sıraları alan iller farklılaşmaktadır. İGE'de 25 il, sağlık endeksinde 39 il, eğitim endeksinde 45 il ve gelir endeksinde 13 il Türkiye ortalamasının üstünde bir değere sahiptir.

İGE'de ilk üç şehir Ankara, Kocaeli ve İstanbul şeklinde sıralanmıştır. Ankara çok yüksek insani gelişmişlik düzeyine çıan tek il olmuştur. 81 il içerisinde 65 il yüksek insani gelişmişlik seviyesinde iken 15 il orta yüksek 
insani gelişmişlik düzeyinde yer almıştır. Endeks değerinde son üç sırada Ağrı, Van ve Şanlıurfa illeri yer almıştır. Bu kapsamda, İGE ile Kalkınma Bakanlığı tarafından hazırlanmış olan İl SEGE çalışması sonuçları arasında büyük oranda benzerlik bulunmuştur. Söz konusu benzerlik İGE'nin illerin insani gelişmişliğinin yanında sosyo-ekonomik yapısı hakkında da önemli bir ipucu verdiğini ortaya koymaktadır.

Sağlık endeksinde ilk üç sırada yer alan şehirler Muğla, Tunceli ve Mardin olurken, son üç sırada Ağrı, Van ve Kilis yer almaktadır. Çalışmada kullanılan tek sağlık değişkeni olan doğumda beklenen yaşam süresi verilerinin birbirine çok yakın olmasından dolayı sağlık endeks değerlerinin birbirine oldukça yakın olduğu görülmüştür. Sağlık endeksinde Türkiye endeks değerinin gelişmekte olan ülkelerin üzerine çıkması ve iller arası değişkenliğin diğer endekslere göre oldukça az olması tüm illerde bu konuda önemli bir ilerleme kaydedildiğini göstermektedir. Söz konusu hususa bin kişi başına düşen yatak kapasitesi, doktor ve sağlık personeli sayısı vb. değişkenler örnek olarak verilebilir.

Eğitim endeksinde ilk üç sırada Ankara, Eskişehir ve Artvin illeri yer almaktadır. Karadeniz illerinin ön sıralarda yer aldığı bu endekste son üç sırada Van, Muş ve Ağrı illeri bulunmaktadır. Karadeniz bölgesinin eğitimde görece avantajlı konumu SEGE çalışması ve benzer gelişmişlik çalışmalarında da göze çarpmaktadır. Karadeniz bölgesinin göç vermesi ile nüfus yoğunluğunun azlığ1 ve eğitim altyapısı yönünden avantajlı olması bu bölge illerini ön plana çıkarmaktadır. Ülke içindeki farklılıkların çok yüksek olduğu bu endeks, ülkemizin genel İGE performansının da düşmesine neden olmaktadır. Gelir endeksi incelendiğinde ise ülkemizde hüküm süren geleneksel bölgeler arası gelişmişlik farklılıkları karşımıza çıkmaktadır. Marmara ve Ege bölgeleri ile Doğu ve Güneydoğu Anadolu bölgeleri arasındaki farklar bu endekste açıkça seçilebilmektedir.

Çalışmada ayrıca İGE ile alt endeksler arasındaki ilişkiler incelenmiştir. Buna göre İGE ile gelir ve eğitim endeksleri arasındaki ilişkinin pozitif yönlü ve güçlü olduğu tespit edilmiştir. Bununla birlikte, İGE ile sağlık endeksi arasında zayıf bir ilişki olduğu görülmüştür. Sağlık endeksine yönelik bu tespit bu endekste kullanılan göstergenin gelişmişliği açılamada yetersiz kalması ile yorumlanabilir. Bu bilgiler ışığında, iller bazındaki İGE değerleri açısından sağlık göstergelerinin İGE'nin oluşturulmasında yeterince ayırt edici olmadığı, gelir alt endeksinde gelir dağılımı verisinin de kullanılmasının illerin İGE değerlerini daha iyi ortaya koyacağı düşünülmektedir. Söz konusu öneriler UNDP ülkeler çalışması için de geçerlidir. Ayrıca, 
sağlık göstergesinin görece avantajlı durumu ve diğer göstergelerin İGE'yle güçlü ilişkisi göz önüne alındığında, Türkiye'nin eğitim ve gelir boyutlarını iyileştirmeye odaklanmasının gelecek yıllardaki İGE sıralama ve değerine önemli ölçüde katkı sağlayarak kısa sürede Türkiye'yi çok yüksek insani gelişmişlik düzeyine taşıyacağı düşünülmektedir. Söz konusu tespit illerin bir üst kategoriye çıkması için de geçerlidir.

Çalışma sonuçları benzer diğer çalışmalarla karşılaştırıldığında illerin sıralaması itibarıyla büyük farklılıklar ortaya çıkmamaktadır. Ayrıca, sosyoekonomik yönden gelişmiş illerin İGE endeks değerlerinin yüksek olduğu, sosyo-ekonomik yönden geri kalmış illerin ise İGE değerlerinin düşük olduğu tespit edilmiştir. Bu kapsamda, illerin sağlık endeksine göre nispi olarak yakın değere sahip olmaları ve diğer göstergelerin önemi dikkate alındığında, gelir ve eğitim politika araçlarına odaklanılmasının bölgesel gelişmişlik farklarının azaltılması açısından da daha etkili olacağı değerlendirilmektedir. 


\section{$\underline{\text { Extended Abstract }}$}

\section{Measuring Human Development Index and Sub-Indices for Turkish Provinces}

\author{
Mustafa Caner Meydan \\ Industry and Technology Specialist
}

\author{
Volkan İdris Sarı \\ Industry and Technology Specialist
}

Until recently, the main objective of policy-makers was to ensure development as a societal goal. Only economic based indicators such as per capita income were used in measuring the level of development. The assumption behind this approach is that the communities with high economic opportunities are more likely to be developed. Over time, data on purely economic performance were evaluated as inadequate to explain the actual experience of people in their socio-economic life. A new model for measuring the welfare of people based on Amartya Sen's capabilities approach has been proposed by the United Nations. The aim of this model is to provide an alternative to the approaches which try to explain the development concept with mere monetary criteria, by measuring the capabilities of people in terms of their basic abilities. Human Development Index (HDI) argues that the per capita income is not a good indicator of development. Because it fails to produce enough information on the differences in income distribution poverty, deprivation, the way income is used by households, and social factors that cannot be measured by income.

United Nations Development Program's HDI compares countries in terms of factors including development, poverty, gender equality, income inequality since 1990. The target of HDI is to create an alternative approach against indexes that focus solely on economic indicators. In this context, HDI is one of the most well-known and important resources and tools for policy makers, academicians, and professional in this area. HDI ranks and classifies the countries as very high, high, medium and low according to their level of 
human development. Policy makers have been implementing additional and new policies to improve counties' conditions by taking HDI into consideration.

Since the index enables comprehensive analyses by using a few variables which are life expectancy at birth, mean years of schooling, expected years of schooling and GNI per capita, it could be used not only for comparing countries but also for measuring the development levels of different provinces within a country. Similar province based studies conducted in 2001 and 2004 for Turkey. This study aims to calculate city-level human development indexes and sub-indexes by using 2014 data for Turkey and differentiates from previous studies by using GDP data which has been published after a long time and by calculating sub-index results in this study. Furthermore, relations between sub-indexes and human development index are analyzed and interpreted.

According to the HDI, Turkey is a high human development country with an index value of 0.767 . Turkey is at the edge of very high human development level since above 0.8 index value is referred to as high human developed country. The country has achieved a big success in health index during the last few years. Life expectancy at birth of Turkey is 75.5 years. Moreover, Turkey has realized an improvement in education sub-index. Mean years of schooling is 7.9 and expected years of schooling is 14.6 years in Turkey. However, income index has a parallel trend across years with USD 18.705.

When it is investigated at province level, only Ankara is at very high level human development level. Most provinces (65 of 81) fall into high human development level. The remaining 15 provinces are in medium human development level. The top three cities are Ankara, Kocaeli and İstanbul, respectively. However, all of the provinces can be defined in very high human development level in health sub-index. Health sub-index values are relatively close to each other and the top three cities are Muğla, Tunceli and Mardin. According to the education sub-index, 58 province falls into medium human development category. Furhermore, 17 provinces are in very high human development category. The top three cities are Ankara, Eskişehir and Artvin. In this context, Ankara and Eskişehir confirm the common belief in terms of education. On the other hand, 6 provinces, which are located in Southeast and East Anatolia regions, are classified in low human development category regarding education sub-index. Moreover, income index is another important determinant of HDI in that the maps prepared by HDI and income sub-index illustrate similar patterns of provinces. Only İstanbul is listed in high human 
development category with respect to income sub-index. While 58 provinces falls into medium human development class, 22 provinces have high human development in income sub-index. The differences between Marmara and Aegean regions, and Eastern and Southeastern Anatolia regions can be clearly noticed in income sub-index.

The correlation between health sub-index and HDI is 33\%. This figure is very low when considering that health is a sub-index of HDI. Thus, the patterns of health sub-index are not fully integrated into HDI and the sub-index partially explains HDI. However, the correlation between education-sub index and HDI is very high with $94.4 \%$. Therefore, education sub-index plays crucial role on ranking of provinces. Interpretation of relationship between income sub-index and HDI is similar to education sub-index as there is a 93.1\% correlation between education sub-index and HDI. Moreover, GDP is the most important factor in HDI since determination coefficient is $87 \%$ in simple regression model. In the light of correlation and regression analyses, health sub-index, so life expectancy at birth, is not adequate to explain HDI. Moreover, income sub-index should cover the distribution of income distribution in a better way. These arguments are valid for global HDI, as well.

As a conclusion, it is observed that human development indexes of cities tend to increase from east to west. It has very similar pattern with socio-economic development index results. In addition, a statistically strong and meaningful relationship was found between the HDI and income and education sub-indices. The authors will update this study with the latest data in the near future.

\section{Kaynakça}

Akder, H. A. (1994). A means to closing gaps: disaggregated human development index (Occasional Paper-18). New York: UNDP Human Development Report Office.

Anand, S., ve Sen, A. K. (1997). Concepts of human development and poverty: a multidimensional perspective (Human development papers 1997), New York: UNDP Human Development Report Office.

Basu, S., ve Basu, P. (2005). Regional disparity in Australia: analysis of gender development index. International Review of Business Research Papers, 1(2), 56-66.

Demir, S. (2006). Birleşmiş Milletler kalkınma programı insani gelişme endeksi ve Türkiye açısından değerlendirme. Ankara: Devlet Planlama Teşkilatı Yayınları.

Demir Şeker, S. (2011). Türkiye'nin insani gelişme endeksi ve endeks stralamasmm analizi. Ankara: Kalkınma Bakanlığı Yayınları.

Despotis, D. K. (2005). A reassessment of the human development index via data envelopment analysis. Journal of the Operational Research Society, 56(8), 969-980. 
Foster, J., Lopez-Calva, L., ve Szekely, M. (2005). Measuring the distribution of human development: methodology and application to Mexico. Journal of Human Development, 6(1), 5-29.

Gasper, D. (2011). Pioneering the human development revolution: analysing the trajectory of Mahbub ul Haq. Journal of Human Development \& Capabilities, 12(3), 433-456.

Haq, M. (1995). Reflections on human development. New York: Oxford University Press.

Hazell, E., Gee, K., ve Sharpe A. (2012). The human development index in Canada: estimates for the Canadian provinces and territories (2000-2011). Ottawa: Centre For The Study Of Living Standards Research Report.

Kahneman, D., ve Deaton A. (2010). High income improves evaluation of life but not emotional well-being. Proceedings of the National Academy of Sciences, 107(38), 16489-16493.

Kalkınma Bakanlığı (2013). İlerin ve bölgelerin sosyo-ekonomik gelişmişlik sıralaması araştırması (SEGE-2011). Ankara: Kalkınma Bakanlığı Yayınları.

Kalkınma Bakanlığı (2014). Bölgesel gelişme ulusal stratejisi (2014-2023). Ankara: Kalkınma Bakanlığı Yayınları.

Klugman, J., Rodríguez F. ve Choi, H.J. (2011). The HDI 2010: new controversies, old critiques (Human Development Research Paper 2011/019. United Nations Development Programme.

Kovacevic, M. (2010). Review of HDI critiques and potential improvements (Human Development Research Paper 2010-33). New York: UNDP-HDRO.

Lind, N. C. (2004). Values Reflected in the Human Development Index. Social Indicators Research, 66(3), 283-293.

Mihçı, H. (2012). Güneydoğu anadolu bölgesindeki insani kalkınma düzeyi (Discussion Paper, No. 2012/82). Ankara: Turkish Economic Association.

Miles, I. (1985). Social indicators for human development. London: Frances Pinter Publishers.

Noorkbakhsh, F. (1998). The human development index: some technical issues and alternative indices. Journal of International Development, 10(5), 589-605.

Noorbakhash, F. (2003). Human development and regional disparities in India (Department of Economics Working Paper No. 12). Glasgow: Glasgow University Press.

Noorbakhsh, F. (2005). Spatial inequality, polarization and its dimensions in Iran: new empirical evidence. Oxford Development Studies, 33(3-4), 473-491.

Oeppen, J., ve Vaupel J.W. (2002). Broken limits to life expectancy. Science's Compass, 296(5570), 1029-1031.

Özpınar, E., ve Koyuncu E. (2016). Türkiye'de insani gelişmişlik iller arasinda nasil farklilaşiyor? 81 il için insani gelişmişlik endeksi (Değerlendirme Notu N201625). Ankara: Türkiye Ekonomi Politikaları Araştırma Vakfı Yayınları.

Porter, J. R., ve Purser, C. W. (2008). Measuring relative sub-national human development: an application of the united nation's human development index using geographic information systems. Journal of Economic and Social Measurement, 33(4), 253-269.

Ravallion, M. (1997). Good and bad growth: the human development reports. World Development, 25(5), 631-638. 
Rigotti, J. I. R., Sawyer, D. O., de Souza, L. R., ve Rodrigues, C. G. (2013). A re-examination of the expected years of schooling: what can it tell us? (International Policy Centre for Inclusive Growth Working Paper Number: 117). Brasilia: United Nations Development Programme.

Riley, J. C. (2005). Poverty and Life Expectancy: The Jamaica Paradox. Cambridge: Cambridge University Press.

Seers, D. (1969). The meaning of development (Communication Series No.44) Institute of Development Studies.

Seth, S. (2009). Inequality, interactions, and human development. Journal of Human Development and Capabilities, 10(3), 375-396.

Silvayand R., ve Ferreira-Lopes A., (2012). A regional human development index for Portugal (Working Paper - 2012/05). Évora: The Center for Advanced Studies in Management and Economics.

Tekeli, İ. (2010). Gündelik yaşam, yaşam kalitesi ve yerellik yazıları. İstanbul: Tarih Vakfı Yurt Yayınları.

Todaro, M., ve Smith, S. (2012). Economic development - 11th edition. Boston: Pearson Addison Wesley.

UNDP (1992). İnsanca gelişme birinci Türkiye konferansı (rapor). Ankara: Birleşmiş Milletler Kalkınma Programı Türkiye Temsilciliği.

UNDP (2001). 2001 Ulusal insani gelişme raporu: Türkiye'nin insani gelişme performansının ölçülmesi. Ankara: Birleşmiş Milletler Kalkınma Programı Türkiye Temsilciliği.

UNDP (2005). Ulusal insani gelişme raporu 2004: bilişim ve iletişim teknolojileri. Ankara: Birleşmiş Milletler Kalkınma Programı Türkiye Temsilciliği.

UNDP (2015a). Training Material for Producing National Human Development Reports. New York: UNDP Human Development Report Office.

Ünal, Ç. (2008). İnsani gelişmişlik endeksine göre Türkiye'nin bölgesel farklılıkları. Coğrafi Bilimler Dergisi, 6(2), 89-113.

Yeşilyurt, M. E., Karadeniz, O., Gülel, F. E., Çağlar, A., ve Kangallı-Uyar, S. G. (2016). Türkiye'de illere göre ortalama ve beklenen okullaşma yıl. Pamukkale Avrasya Sosyoekonomik Çalışmalar Dergisi, 3(1). 1-7.

\section{İnternet Kaynakları}

Ismail A., ve Gosavi V. (2010). Human development index and human poverty index for Indian states 2005: Multivariate Statistical Analysis of basic indicators. 28 Ekim 2017 tarihinde, http://lup.lub.lu.se/luur/download?func=downloadFile\&recordOId=1609681\&fileOId=1609685 adresinden erişildi.

İnsani Gelişme Vakfı (2017). İnsani Gelişme Endeksi - İlçeler. 18.01.2017 tarihinde, http://ingev.org/wp-content/uploads/2017/10/IGE-I-ozet.pdf adresinden erişildi.

Maddison, A. (2010). Historical Statistics of the World Economy. 12.12.2017 tarihinde http://www.ggdc.net/maddison/historical_statistics/horizontal-file_02-2010.xls adresinden erişildi.

Milli Eğitim Bakanlı̆̆ (MEB), Resmi istatistikler. 17.12.2017 tarihinde, http://sgb.meb.gov.tr/www/resmi-istatistikler/icerik/64 erişim sağlandı. 
Türkiye İstatistik Kurumu (TÜİ), Bölgesel istatistikler. 15.12.2017 tarihinde, https://biruni.tuik.gov.tr/bolgeselistatistik/\# adresinden erişildi.

UNDP (2014). Özet 2014 İnsani Gelişme Raporu İnsani İlerlemeyi Sürdürmek: Kırılganlıkları Azaltmak ve Dayanıklılk Oluşturmak. 21.10.2018 tarihinde, http://www.tr.undp.org/content/turkey/tr/home/library/human_development/hdr-2014.html adresinden erişildi.

UNDP (2015b). Özet 2015 Insani Gelişme Raporu: İnsani Gelişme İçin Çalışma. 21.10.2018 tarihinde, $\quad$ http://www.tr.undp.org/content/dam/turkey/docs/Publications/hdr/2015\%20\%C4\%B0nsani\%20Geli\%C5\%9Fme\%20Raporu $\% 20 \%$ C3\%96zeti\%20V5.pdf adresinden erişildi.

UNDP (2016a). Özet 2016 İnsani Gelişme Raporu: Herkes İçin İnsani Gelişme. 21.10.2018 tarihinde, http://www.tr.undp.org/content/dam/turkey/docs/hdr2016/HDR\%202016\%20Overview\%20TR.pdf adresinden erişildi.

UNDP (2016b). Human Development Report 2016. Technical Notes. 17.12.2016 tarihinde, http://hdr.undp.org/sites/default/files/hdr2016_technical_notes.pdf adresinden erişildi.

UNDP (2017a). Human Development Reports. 13.03.2017 tarihinde, www.hdr.undp.org adresinden erişildi.

UNDP (2017b). Human Development Data (1990-2015). 18.03.2017 tarihinde http://hdr.undp.org/en/data adresinden erişildi.

UNDP (2018). Ulusal Insani Gelişme Raporları 11.02.2018 tarihinde http://www.tr.undp.org/content/turkey/tr/home/library/national-hdrs.html adresinden erişildi.

UNESCO (2013). UIS Methodology for Estimation of Mean Years of Schooling. 10.01.2018 tarihinde http:/uis.unesco.org/sites/default/files/documents/uis-methodology-for-estimation-of-mean-years-of-schooling-2013-en_0.pdf adresinden erişildi.

Yükseköğretim Kurulu (YÖK), 2014-2015 Öğretim Yllı Yükseköğretim İstatistikleri. 09.12.2016 tarihinde https://istatistik.yok.gov.tr/ adresinden erişildi. 


\section{Ek-1: Yıllar İtibarıyla İGE'de Yapılan Değişiklikler}

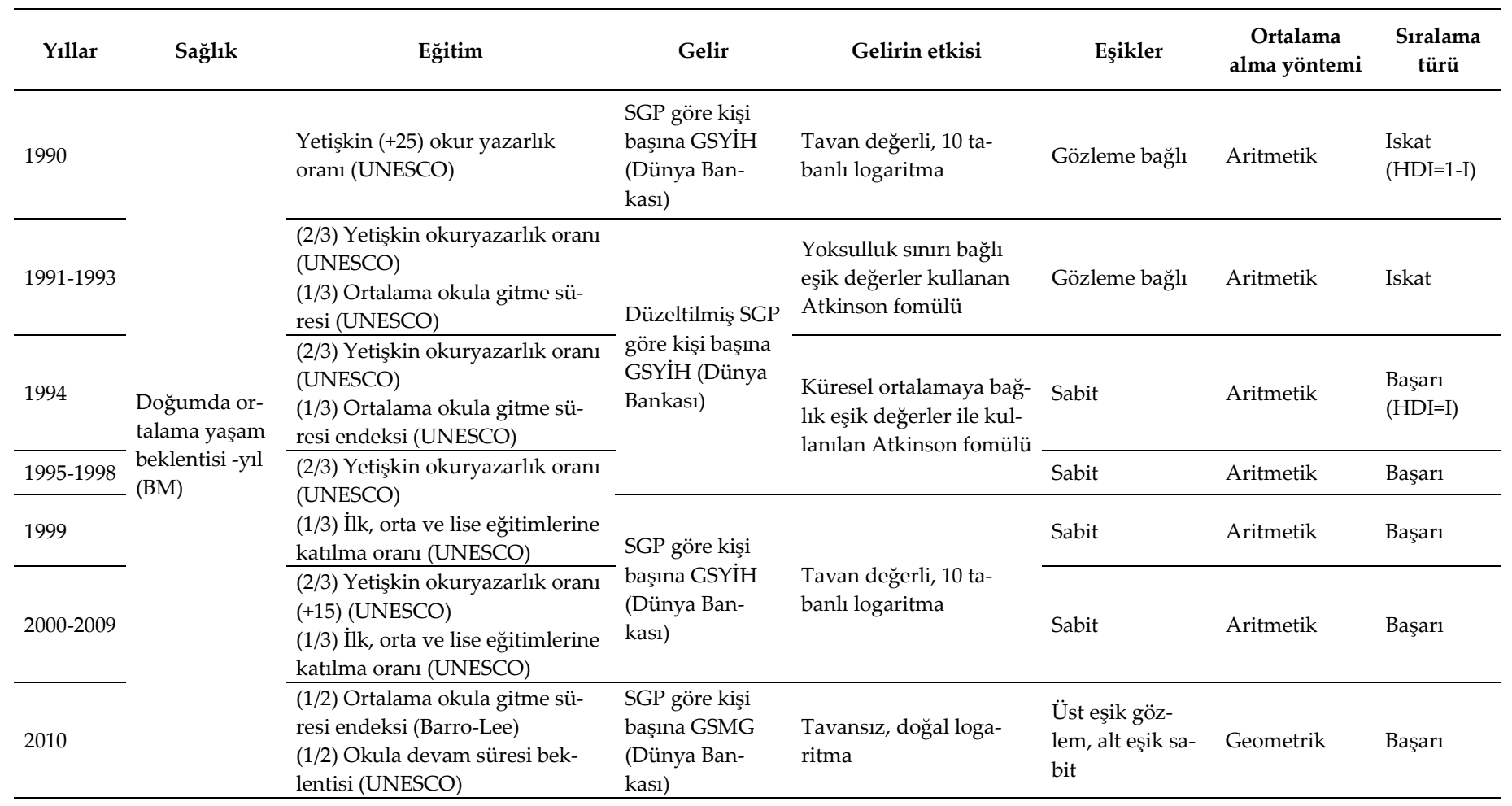

Kaynak: Kovacevic $(2010,4)$ ve UNDP (2015a, 32-34)'den faydalanılarak hazırlanmıştır. 


\section{Ek-2: Endekslerin Hesaplanma Yöntemleri ${ }^{13}$}

$$
\dot{\mathrm{I} G E}=(\text { SağllkEndeksi }+ \text { Eğitim Endeksi }+ \text { Gelir Endeksi })^{1 / 3}
$$

\section{Sağlık Endeksi}

$$
\text { Să̆llk Endeksi }=\frac{x_{i j}-x_{\text {min }}}{x_{\max }-x_{\min }}
$$

Formülde;

- $\quad X_{\mathrm{ij}}$ değeri beklenen yaşam süresini,

- $\quad X_{\text {min }}$ değeri minimum yaşam süresi olan 20 yılı,

- $\quad X_{\max }$ değeri maksimum yaşam süresi olan 85 yılı göstermektedir.

\section{Eğitim Endeksi}

$$
\text { Ĕ̌itim Endeksi }=\frac{B O Y \text { Endeksi }+O O Y \text { Endeksi }}{2}
$$

(a) Ortalama Okullaşma Yılı Endeksi (OOY)

Formülde;

$$
O O Y \text { Endeksi }=\frac{\sum_{\alpha=1}^{k} \sum_{l=1}^{c} H S_{\alpha l} * Y S_{\propto l}}{9}
$$

- $\quad \alpha$ yaş gruplarını $(1=25-29,2=30-34,3=35-39,4=40-44,5=45-49,6=$ $50-54,7=55-59,8=60-64,9=65+)$

- $\quad 1$ öğretim kademesini (1=İlkokul, 2=İlköğretim, 3= Ortaokul veya Dengi Meslek Ortaokul, 4= Lise veya Dengi Meslek Okulu, 5= Yüksekokul veya Fakülte, 6= Yüksek Lisans (5 veya 6 Yillık Fakülteler Dahil), 7= Doktora)

- HS $\quad$ l l leğitim düzeyine göre $\alpha$ yaş grubundaki mezunların nüfusa oranını (net okullaşma oranı)

- YSol l eğitim düzeyinin eğitim yılını göstermektedir.

(b) Beklenen Okullaşma Yı1ı Endeksi (BOY)

$$
\text { BOY Endeksi }=\sum_{l=1}^{c} n * E R_{l}
$$

${ }^{13}$ Kaynak: UNDP (2017b) 
Formülde;

- (1) öğretim kademesini (1=Okulöncesi, 2=İlkokul, 3=Ortaokul, 4=Ortaöğretim/Lise, 5=Genel Ortaöğretim, 6= Mesleki ve Teknik Ortaöğretim)

- (n) öğretim süresini (Okulöncesi 3-5 yaş olduğu için 3 yıl, İlkokul için 4 yıl, Ortaokul için 4 yıl, Ortaöğretim/Lise, Genel Ortaöğretim ve Mesleki ve Teknik Ortaöğretim için 4 yıl)

- $\quad$ (ER) öğretim kademesinin okullaşma oranını göstermektedir.

\section{Gelir Endeksi}

Formülde;

$$
\text { Gelir endeksi }=\frac{\ln x_{i j}-\ln x_{\min }}{\ln x_{\max }-\ln x_{\min }}
$$

- $\quad$ Xij değeri ilin kişi başı GSYİH'sını (ABD Doları), (TÜİK, 2014)

- $\quad$ Xmin değeri hipotetik olarak alınan minimum kişi başı GSYIH miktarı olan 100 ABD Doları'nı,

- $\quad$ Xmax değeri maksimum kişi başı GSYİH miktarı olan 75.000 ABD Doları'nı göstermektedir.

\section{Kategorizasyon}

- $\quad$ Endeks değeri $\geq 0,80$ ise Çok Yüksek İnsani Gelişmişlik (ÇYİG)

- $\quad 0,80>$ Endeks değeri $\geq 0,70$ ise Yüksek İnsani Gelişmişlik (YİG)

- $\quad 0,70>$ Endeks değeri $\geq 0,55$ ise Orta Yüksek İnsani Gelişmişlik (OYİG)

- $\quad$ Endeks değeri < 0,55 ise Düşük İnsani Gelişmişlik (DİG)

\section{V. İl Bazında İnsani Gelişme Endeksinde Kullanılan Değişkenler}

\begin{tabular}{|l|l|c|}
\hline \multicolumn{1}{|c|}{ Değişken Adı } & Veri Kaynağı & Veri Yılı \\
\hline Doğumda Beklenen Yaşam Süresi & TÜİK & 2014 \\
\hline Nüfus & TÜİK & 2014 \\
\hline Ö̆ğretim Düzeyine Göre Mezun Sayısı & TÜİK-YÖK & 2014 \\
\hline Öğretim Düzeyine Göre Okullaşma Oranı & TÜİK-MEB & 2014 \\
\hline Kişi Başı GSYİH & TÜİK & 2014 \\
\hline
\end{tabular}




\section{Ek-3: İl Bazında İGE Değerleri, Sıralaması ve Kategorileri}

\begin{tabular}{|c|c|c|c|c|c|c|c|}
\hline İller & $\begin{array}{c}\text { İGE Endeks } \\
\text { Değeri }\end{array}$ & $\begin{array}{c}\text { İGE S1- } \\
\text { rası }\end{array}$ & Kategori & İller & $\begin{array}{l}\text { İGE En- } \\
\text { deks De- } \\
\text { ğeri }\end{array}$ & $\begin{array}{c}\text { İGE } \\
\text { S1- } \\
\text { ras1 } \\
\end{array}$ & $\begin{array}{c}\text { Kate- } \\
\text { gori }\end{array}$ \\
\hline Türkiye & 0,757 & & YİG & Zonguldak & 0,741 & 41 & YİG \\
\hline Ankara & 0,809 & 1 & ÇYİG & Konya & 0,740 & 42 & YİG \\
\hline Kocaeli & 0,795 & 2 & YİG & Nevşehir & 0,739 & 43 & YİG \\
\hline İstanbul & 0,795 & 3 & YİG & Sinop & 0,739 & 44 & YİG \\
\hline Bolu & 0,788 & 4 & YİG & Sivas & 0,738 & 45 & YİG \\
\hline İzmir & 0,785 & 5 & YİG & Adana & 0,737 & 46 & YİG \\
\hline Eskişehir & 0,785 & 6 & YİG & Çankırı & 0,737 & 47 & YİG \\
\hline Bilecik & 0,783 & 7 & YİG & Bartın & 0,736 & 48 & YİG \\
\hline Yalova & 0,780 & 8 & YİG & Malatya & 0,736 & 49 & YİG \\
\hline Muğla & 0,779 & 9 & YİG & Elazı $\breve{g}$ & 0,735 & 50 & YİG \\
\hline Antalya & 0,776 & 10 & YİG & Niğde & 0,729 & 51 & YİG \\
\hline Rize & 0,776 & 11 & YİG & Çorum & 0,728 & 52 & YİG \\
\hline Trabzon & 0,775 & 12 & YİG & Ordu & 0,727 & 53 & YİG \\
\hline Artvin & 0,775 & 13 & YİG & A.Karahisar & 0,726 & 54 & YİG \\
\hline Kırklareli & 0,773 & 14 & YİG & Osmaniye & 0,726 & 55 & YİG \\
\hline Tekirdă̆ & 0,771 & 15 & YİG & Hatay & 0,723 & 56 & YİG \\
\hline Bursa & 0,771 & 16 & YİG & Bayburt & 0,719 & 57 & YİG \\
\hline Çanakkale & 0,769 & 17 & YİG & Aksaray & 0,716 & 58 & YİG \\
\hline Tunceli & 0,768 & 18 & YİG & Gümüşhane & 0,716 & 59 & YİG \\
\hline Isparta & 0,766 & 19 & YİG & Tokat & 0,716 & 60 & YİG \\
\hline Denizli & 0,764 & 20 & YİG & K.Maraş & 0,712 & 61 & YİG \\
\hline Edirne & 0,763 & 21 & YİG & Gaziantep & 0,710 & 62 & YİG \\
\hline Karaman & 0,763 & 22 & YİG & Yozgat & 0,709 & 63 & YİG \\
\hline Karabük & 0,762 & 23 & YİG & Adiyaman & 0,709 & 64 & YİG \\
\hline Erzincan & 0,761 & 24 & YİG & Ardahan & 0,704 & 65 & YİG \\
\hline Burdur & 0,758 & 25 & YİG & Erzurum & 0,703 & 66 & YİG \\
\hline Sakarya & 0,757 & 26 & YİG & Kilis & 0,697 & 67 & OYİG \\
\hline Balıkesir & 0,756 & 27 & YİG & Iğdır & 0,689 & 68 & OYİG \\
\hline Amasya & 0,755 & 28 & YİG & Kars & 0,684 & 69 & OYİG \\
\hline Düzce & 0,753 & 29 & YİG & Bingöl & 0,683 & 70 & OYİG \\
\hline Kayseri & 0,753 & 30 & YİG & Mardin & 0,682 & 71 & OYİG \\
\hline Kırıkkale & 0,752 & 31 & YİG & Batman & 0,680 & 72 & OYİG \\
\hline Mersin & 0,751 & 32 & YİG & Diyarbakır & 0,676 & 73 & OYİG \\
\hline Uşak & 0,750 & 33 & YİG & Siirt & 0,673 & 74 & OYİG \\
\hline Aydın & 0,750 & 34 & YİG & Bitlis & 0,666 & 75 & OYİG \\
\hline Manisa & 0,748 & 35 & YİG & Şırnak & 0,657 & 76 & OYİG \\
\hline Kütahya & 0,746 & 36 & YİG & Hakkari & 0,656 & 77 & OYİG \\
\hline Samsun & 0,744 & 37 & YİG & Muş & 0,645 & 78 & OYİG \\
\hline Kırşehir & 0,744 & 38 & YİG & Şanlıurfa & 0,641 & 79 & OYİG \\
\hline Giresun & 0,743 & 39 & YİG & Van & 0,634 & 80 & OYİG \\
\hline Kastamonu & 0,742 & 40 & YİG & Ağrn & 0,617 & 81 & OYİG \\
\hline
\end{tabular}

Kaynak: Yazarlar tarafından oluşturulmuştur.

ÇYİG: Çok yüksek insani gelişmişlik

YİG: Yüksek insani gelişmişlik

OYİG: Orta yüksek insani gelişmişlik 


\section{Ek-4: İllerin Sağlık Endeksi Değerleri ve Sıralaması}

\begin{tabular}{|c|c|c|c|c|c|c|c|}
\hline İller & $\begin{array}{c}\text { Sağllk } \\
\text { Endeksi } \\
\text { Değeri }\end{array}$ & $\begin{array}{l}\text { Sağlık } \\
\text { Endeksi } \\
\text { Sırası }\end{array}$ & Kategori & İller & $\begin{array}{c}\text { Sağllk } \\
\text { En- } \\
\text { deksi } \\
\text { Değeri }\end{array}$ & $\begin{array}{c}\text { Sağlik } \\
\text { En- } \\
\text { deksi } \\
\text { Sirasi }\end{array}$ & $\begin{array}{c}\text { Kate- } \\
\text { gori }\end{array}$ \\
\hline Türkiye & 0,892 & & ÇYİG & Kayseri & 0,892 & 41 & ÇYİG \\
\hline Muğla & 0,931 & 1 & ÇYİG & Şırnak & 0,892 & 42 & ÇYİG \\
\hline Tunceli & 0,931 & 2 & ÇYİG & Kocaeli & 0,891 & 43 & ÇYİG \\
\hline Mardin & 0,928 & 3 & ÇYİG & Hatay & 0,891 & 44 & ÇYİG \\
\hline Giresun & 0,925 & 4 & ÇYİG & Zonguldak & 0,891 & 45 & ÇYİG \\
\hline Gümüşhane & 0,922 & 5 & ÇYİG & Siirt & 0,891 & 46 & ÇYİG \\
\hline Trabzon & 0,920 & 6 & ÇYİG & Sivas & 0,889 & 47 & ÇYİG \\
\hline Ordu & 0,920 & 7 & ÇYİG & Yozgat & 0,889 & 48 & ÇYİG \\
\hline Rize & 0,917 & 8 & ÇYİG & Amasya & 0,889 & 49 & ÇYİG \\
\hline Adıyaman & 0,915 & 9 & ÇYİG & Bingöl & 0,889 & 50 & ÇYİG \\
\hline Ankara & 0,914 & 10 & ÇYİG & Edirne & 0,888 & 51 & ÇYİG \\
\hline Artvin & 0,912 & 11 & ÇYİG & Çanakkale & 0,888 & 52 & ÇYİG \\
\hline Bolu & 0,911 & 12 & ÇYİG & Bilecik & 0,888 & 53 & ÇYİG \\
\hline Antalya & 0,911 & 13 & ÇYİG & Düzce & 0,888 & 54 & ÇYİG \\
\hline K.Maraş & 0,909 & 14 & ÇYİG & Kars & 0,888 & 55 & ÇYİG \\
\hline Erzincan & 0,909 & 15 & ÇYİG & Ballkesir & 0,886 & 56 & ÇYİG \\
\hline Karaman & 0,908 & 16 & ÇYİG & Nevşehir & 0,886 & 57 & ÇYİG \\
\hline İzmir & 0,905 & 17 & ÇYİG & Bartın & 0,886 & 58 & ÇYİG \\
\hline Denizli & 0,905 & 18 & ÇYİG & Tokat & 0,886 & 59 & ÇYİG \\
\hline Malatya & 0,905 & 19 & ÇYİG & Bursa & 0,885 & 60 & ÇYİG \\
\hline İstanbul & 0,903 & 20 & ÇYİG & Eskişehir & 0,885 & 61 & ÇYİG \\
\hline Aydın & 0,903 & 21 & ÇYİG & Sakarya & 0,885 & 62 & ÇYİG \\
\hline Isparta & 0,903 & 22 & ÇYİG & Kastamonu & 0,885 & 63 & ÇYİG \\
\hline Batman & 0,903 & 23 & ÇYİG & Bayburt & 0,885 & 64 & ÇYİG \\
\hline Yalova & 0,902 & 24 & ÇYİG & Muş & 0,885 & 65 & ÇYİG \\
\hline Burdur & 0,902 & 25 & ÇYİG & Bitlis & 0,885 & 66 & ÇYİG \\
\hline Osmaniye & 0,902 & 26 & ÇYİG & Manisa & 0,883 & 67 & ÇYİG \\
\hline Sinop & 0,902 & 27 & ÇYİG & Adana & 0,883 & 68 & ÇYİG \\
\hline Karabük & 0,900 & 28 & ÇYİG & Şanlıurfa & 0,883 & 69 & ÇYİG \\
\hline Elazığ & 0,900 & 29 & ÇYİG & Erzurum & 0,882 & 70 & ÇYİG \\
\hline Niğde & 0,898 & 30 & ÇYİG & Hakkari & 0,882 & 71 & ÇYİG \\
\hline Mersin & 0,897 & 31 & ÇYİG & Tekirdağ & 0,878 & 72 & ÇYİG \\
\hline Çorum & 0,897 & 32 & ÇYİG & Kırklareli & 0,878 & 73 & ÇYİG \\
\hline Iğğır & 0,897 & 33 & ÇYİG & Kırıkkale & 0,878 & 74 & ÇYİG \\
\hline Aksaray & 0,895 & 34 & ÇYİG & A.Karahisar & 0,877 & 75 & ÇYİG \\
\hline Kırşehir & 0,895 & 35 & ÇYİG & Kütahya & 0,875 & 76 & ÇYİG \\
\hline Çankırı & 0,895 & 36 & ÇYİG & Gaziantep & 0,872 & 77 & ÇYİG \\
\hline Diyarbakır & 0,895 & 37 & ÇYİG & Ardahan & 0,871 & 78 & ÇYİG \\
\hline Konya & 0,894 & 38 & ÇYİG & Ağr1 & 0,855 & 79 & ÇYİG \\
\hline Samsun & 0,894 & 39 & ÇYİG & Van & 0,855 & 80 & ÇYİG \\
\hline Uşak & 0,892 & 40 & ÇYİG & Kilis & 0,846 & 81 & ÇYİG \\
\hline
\end{tabular}

Kaynak: Yazarlar tarafından oluşturulmuştur.

ÇYİG: Çok yüksek insani gelişmişlik 


\section{Ek-5: İllerin Ortalama ve Beklenen Okullașma Yılı}

\begin{tabular}{|c|c|c|c|c|c|}
\hline İller & OOY & BOY & İller & OOY & BOY \\
\hline Türkiye & 7,66 & 14,96 & İzmir & 8,55 & 15,46 \\
\hline Adana & 7,63 & 14,90 & Kahramanmaraş & 6,61 & 14,17 \\
\hline Adiyaman & 6,45 & 14,73 & Karabük & 7,89 & 16,19 \\
\hline Afyon & 7,18 & 14,93 & Karaman & 7,39 & 15,82 \\
\hline Ăgrn & 4,63 & 12,33 & Kars & 6,26 & 13,71 \\
\hline Aksaray & 6,62 & 14,18 & Kastamonu & 7,17 & 15,81 \\
\hline Amasya & 7,74 & 16,63 & Kayseri & 7,69 & 15,25 \\
\hline Ankara & 9,28 & 15,87 & Kırıkkale & 8,25 & 15,74 \\
\hline Antalya & 7,93 & 15,41 & Kirklareli & 8,25 & 15,90 \\
\hline Ardahan & 6,62 & 15,09 & Kırşehir & 7,78 & 15,64 \\
\hline Artvin & 8,25 & 16,43 & Kilis & 6,84 & 14,87 \\
\hline Aydin & 7,74 & 15,59 & Kocaeli & 8,08 & 15,74 \\
\hline Balıkesir & 7,99 & 15,56 & Konya & 7,28 & 14,91 \\
\hline Bartın & 7,02 & 16,11 & Kütahya & 7,39 & 16,19 \\
\hline Batman & 5,78 & 13,91 & Malatya & 7,59 & 15,63 \\
\hline Bayburt & 7,08 & 14,87 & Manisa & 7,17 & 15,34 \\
\hline Bilecik & 8,02 & 16,13 & Mardin & 5,24 & 13,51 \\
\hline Bingöl & 5,77 & 14,06 & Mersin & 7,65 & 15,40 \\
\hline Bitlis & 5,57 & 13,18 & Muğla & 8,17 & 15,36 \\
\hline Bolu & 7,93 & 16,39 & Muş & 4,95 & 12,23 \\
\hline Burdur & 7,69 & 15,43 & Nevşehir & 7,46 & 15,40 \\
\hline Bursa & 8,01 & 15,50 & Niğde & 7,23 & 14,81 \\
\hline Çanakkale & 8,06 & 15,76 & Ordu & 6,95 & 15,32 \\
\hline Çankırı & 7,62 & 14,67 & Osmaniye & 7,39 & 14,75 \\
\hline Çorum & 6,95 & 15,17 & Rize & 7,70 & 16,99 \\
\hline Denizli & 7,70 & 15,57 & Sakarya & 7,61 & 15,62 \\
\hline Düzce & 7,36 & 15,59 & Samsun & 7,30 & 15,78 \\
\hline Edirne & 7,99 & 15,92 & Siirt & 5,43 & 13,71 \\
\hline Elazığ & 7,15 & 15,54 & Sinop & 7,38 & 15,61 \\
\hline Erzincan & 7,54 & 15,81 & Sivas & 7,38 & 15,40 \\
\hline Erzurum & 6,81 & 13,91 & Şırnak & 4,51 & 13,43 \\
\hline Eskişehir & 8,79 & 16,16 & Tekirdağ & 7,95 & 15,21 \\
\hline Gaziantep & 6,53 & 14,08 & Tokat & 7,08 & 15,24 \\
\hline Giresun & 7,37 & 16,21 & Trabzon & 7,91 & 16,60 \\
\hline Gümüşhane & 7,24 & 12,78 & Tunceli & 7,87 & 15,68 \\
\hline Hakkâri & 5,33 & 12,82 & Uşak & 7,51 & 15,48 \\
\hline Hatay & 6,81 & 15,19 & Van & 5,04 & 12,60 \\
\hline Iğdır & 5,84 & 14,02 & Yalova & 8,42 & 15,66 \\
\hline Isparta & 8,17 & 16,15 & Yozgat & 6,86 & 14,15 \\
\hline İstanbul & 8,25 & 15,14 & Zonguldak & 7,38 & 15,74 \\
\hline
\end{tabular}

Kaynak: Yazarlar tarafından oluşturulmuştur. 


\section{Ek-6: İllerin Eğitim Endeksi Değerleri ve Sıralaması}

\begin{tabular}{|c|c|c|c|c|c|c|c|}
\hline İller & $\begin{array}{l}\text { Eğitim En- } \\
\text { deksi De- } \\
\text { ğeri }\end{array}$ & $\begin{array}{c}\text { Eğitim } \\
\text { Endeksi } \\
\text { Sirası }\end{array}$ & Kategori & İller & $\begin{array}{c}\text { Eğitim } \\
\text { Endeksi } \\
\text { Değeri }\end{array}$ & $\begin{array}{c}\text { Eğitim } \\
\text { Endeksi } \\
\text { Sirası }\end{array}$ & Kategori \\
\hline Türkiye & 0,671 & & OYİG & Sinop & 0,680 & 41 & OYİG \\
\hline Ankara & 0,750 & 1 & YİG & Düzce & 0,679 & 42 & OYİG \\
\hline Eskişehir & 0,742 & 2 & YİG & Kastamonu & 0,678 & 43 & OYİG \\
\hline Artvin & 0,731 & 3 & YİG & Nevşehir & 0,677 & 44 & OYİG \\
\hline Rize & 0,729 & 4 & YİG & Sivas & 0,674 & 45 & OYİG \\
\hline Trabzon & 0,725 & 5 & YİG & Elazığ & 0,670 & 46 & OYİG \\
\hline Isparta & 0,721 & 6 & YİG & Adana & 0,668 & 47 & OYİG \\
\hline Amasya & 0,720 & 7 & YİG & Manisa & 0,665 & 48 & OYİG \\
\hline Bolu & 0,720 & 8 & YİG & Çankırı & 0,662 & 49 & OYİG \\
\hline Kırklareli & 0,717 & 9 & YİG & Tokat & 0,659 & 50 & OYİG \\
\hline Yalova & 0,716 & 10 & YİG & Ordu & 0,657 & 51 & OYİG \\
\hline Bilecik & 0,715 & 11 & YİG & Konya & 0,657 & 52 & OYİG \\
\hline İzmir & 0,714 & 12 & YİG & Osmaniye & 0,656 & 53 & OYİG \\
\hline Karabük & 0,713 & 13 & YİG & A.Karahisar & 0,654 & 54 & OYİG \\
\hline Kirıkkale & 0,712 & 14 & YİG & Çorum & 0,653 & 55 & OYİG \\
\hline Edirne & 0,709 & 15 & YİG & Niğde & 0,652 & 56 & OYİG \\
\hline Kocaeli & 0,707 & 16 & YİG & Bayburt & 0,649 & 57 & OYİG \\
\hline Çanakkale & 0,706 & 17 & YİG & Hatay & 0,649 & 58 & OYİG \\
\hline Muğla & 0,699 & 18 & OYİG & Kilis & 0,641 & 59 & OYİG \\
\hline Balıkesir & 0,699 & 19 & OYİG & Ardahan & 0,640 & 60 & OYİG \\
\hline Tunceli & 0,698 & 20 & OYİG & Adıyaman & 0,624 & 61 & OYİG \\
\hline Bursa & 0,697 & 21 & OYİG & Yozgat & 0,622 & 62 & OYİG \\
\hline Kütahya & 0,696 & 22 & OYİG & Aksaray & 0,615 & 63 & OYİG \\
\hline Giresun & 0,696 & 23 & OYİG & K.Maraş & 0,614 & 64 & OYİG \\
\hline İstanbul & 0,696 & 24 & OYİG & Erzurum & 0,613 & 65 & OYİG \\
\hline Kırşehir & 0,694 & 25 & OYİG & Gaziantep & 0,609 & 66 & OYİG \\
\hline Antalya & 0,692 & 26 & OYİG & Gümüşhane & 0,596 & 67 & OYİG \\
\hline Aydın & 0,691 & 27 & OYİG & Kars & 0,590 & 68 & OYİG \\
\hline Erzincan & 0,691 & 28 & OYİG & Iğdır & 0,584 & 69 & OYİG \\
\hline Denizli & 0,689 & 29 & OYİG & Bingöl & 0,583 & 70 & OYİG \\
\hline Sakarya & 0,688 & 30 & OYİG & Batman & 0,579 & 71 & OYİG \\
\hline Tekirdağ & 0,687 & 31 & OYİG & Siirt & 0,562 & 72 & OYİG \\
\hline Malatya & 0,687 & 32 & OYİG & Diyarbakır & 0,560 & 73 & OYİG \\
\hline Karaman & 0,686 & 33 & OYİG & Bitlis & 0,552 & 74 & OYİG \\
\hline Burdur & 0,685 & 34 & OYİG & Mardin & 0,550 & 75 & OYİG \\
\hline Zonguldak & 0,683 & 35 & OYİG & Hakkari & 0,533 & 76 & DİG \\
\hline Mersin & 0,683 & 36 & OYİG & Şırnak & 0,523 & 77 & DİG \\
\hline Samsun & 0,682 & 37 & OYİG & Şanlıurfa & 0,519 & 78 & DİG \\
\hline Bartın & 0,681 & 38 & OYİG & Van & 0,518 & 79 & DİG \\
\hline Uşak & 0,680 & 39 & OYİG & Muş & 0,505 & 80 & DİG \\
\hline Kayseri & 0,680 & 40 & OYİG & Ağr1 & 0,497 & 81 & DİG \\
\hline
\end{tabular}

Kaynak: Yazarlar tarafından oluşturulmuştur.

YİG: Yüksek insani gelişmişlik

OYİG: Orta yüksek insani gelişmişlik

DİG: Düşük insani gelişmişlik 
Ek-7: İllerin Gelir Endeksi Değerleri ve Sıralaması

\begin{tabular}{|c|c|c|c|c|c|c|c|}
\hline îller & $\begin{array}{c}\text { Gelir Endeksi } \\
\text { Değeri }\end{array}$ & \begin{tabular}{|c|} 
Gelir En- \\
deksi Sırası \\
\end{tabular} & Kategori & iller & $\begin{array}{c}\text { Gelir Endeksi } \\
\text { Değeri }\end{array}$ & $\begin{array}{c}\text { Gelir Endeksi } \\
\text { Sırası } \\
\end{array}$ & Kategori \\
\hline Türkiye & 0,725 & & YİG & Nevşehir & 0,674 & 41 & OYİG \\
\hline Istanbul & 0,800 & 1 & ÇYİG & Amasya & 0,674 & 42 & OYİG \\
\hline Kocaeli & 0,800 & 2 & ÇYİG & Gaziantep & 0,673 & 43 & OYİG \\
\hline Ankara & 0,774 & 3 & YİG & Sivas & 0,670 & 44 & OYİG \\
\hline Tekirdağ & 0,759 & 4 & YİG & Zonguldak & 0,670 & 45 & OYİG \\
\hline Bilecik & 0,756 & 5 & YİG & Gümüşhane & 0,669 & 46 & OYİG \\
\hline Izmir & 0,749 & 6 & YİG & Aksaray & 0,668 & 47 & OYİG \\
\hline Bolu & 0,747 & 7 & YİG & A.Karahisar & 0,668 & 48 & OYİG \\
\hline Bursa & 0,743 & 8 & YİG & Kurşehir & 0,663 & 49 & OYİG \\
\hline Antalya & 0,742 & 9 & YİG & Niğde & 0,662 & 50 & OYİG \\
\hline Eskişehir & 0,737 & 10 & YİG & Bartın & 0,660 & 51 & OYİG \\
\hline Yalova & 0,736 & 11 & YİG & Sinop & 0,659 & 52 & OYİG \\
\hline Kurklareli & 0,732 & 12 & YİG & Çorum & 0,658 & 53 & OYİG \\
\hline Muğla & 0,728 & 13 & YİG & Elazığ & 0,657 & 54 & OYİG \\
\hline Çanakkale & 0,725 & 14 & YİG & Hatay & 0,655 & 55 & OYİG \\
\hline Denizli & 0,714 & 15 & YİG & Osmaniye & 0,647 & 56 & OYİG \\
\hline Karaman & 0,713 & 16 & YİG & Bayburt & 0,647 & 57 & OYİG \\
\hline Sakarya & 0,712 & 17 & YİG & K.Maraş & 0,646 & 58 & OYİG \\
\hline Manisa & 0,712 & 18 & YİG & Yozgat & 0,645 & 59 & OYİG \\
\hline Düzce & 0,710 & 19 & YİG & Erzurum & 0,643 & 60 & OYİG \\
\hline Edirne & 0,706 & 20 & YİG & Malatya & 0,641 & 61 & OYİG \\
\hline Burdur & 0,705 & 21 & YİG & Giresun & 0,638 & 62 & OYİG \\
\hline Kayseri & 0,704 & 22 & YİG & Ordu & 0,634 & 63 & OYİG \\
\hline Erzincan & 0,703 & 23 & YİG & Tokat & 0,629 & 64 & OYİG \\
\hline Rize & 0,699 & 24 & OYİG & Ardahan & 0,627 & 65 & OYİG \\
\hline Tunceli & 0,699 & 25 & OYİG & Iğdır & 0,625 & 66 & OYİG \\
\hline Balıkesir & 0,698 & 26 & OYİG & Kilis & 0,624 & 67 & OYİG \\
\hline Trabzon & 0,697 & 27 & OYİG & Adiyaman & 0,623 & 68 & OYİG \\
\hline Artvin & 0,697 & 28 & OYİG & Mardin & 0,620 & 69 & OYİG \\
\hline Uşak & 0,696 & 29 & OYİG & Bingöl & 0,615 & 70 & OYİG \\
\hline Mersin & 0,691 & 30 & OYİG & Diyarbakır & 0,615 & 71 & OYİG \\
\hline Karabük & 0,690 & 31 & OYİG & Kars & 0,610 & 72 & OYİG \\
\hline Konya & 0,689 & 32 & OYİG & Siirt & 0,608 & 73 & OYİG \\
\hline Isparta & 0,689 & 33 & OYİG & Şırnak & 0,607 & 74 & OYİG \\
\hline Kastamonu & 0,682 & 34 & OYİG & Bitlis & 0,606 & 75 & OYİG \\
\hline Kütahya & 0,681 & 35 & OYİG & Batman & 0,602 & 76 & OYİG \\
\hline Kırıkkale & 0,679 & 36 & OYİG & Muş & 0,602 & 77 & OYİG \\
\hline Adana & 0,677 & 37 & OYİG & Hakkari & 0,601 & 78 & OYİG \\
\hline Samsun & 0,676 & 38 & OYİG & Van & 0,576 & 79 & OYİG \\
\hline Aydın & 0,675 & 39 & OYİG & Şanliurfa & 0,574 & 80 & OYİG \\
\hline Çankırı & 0,675 & 40 & OYİG & Ăgrn & 0,553 & 81 & OYİG \\
\hline
\end{tabular}

Kaynak: Yazarlar tarafından oluşturulmuştur.

ÇYİG: Çok yüksek insani gelişmişlik

YİG: Yüksek insani gelişmişlik

OYİG: Orta yüksek insani gelişmişlik 
İnsani Gelişme Endeksi ve Alt Endekslerinin Türkiye'deki İller İçin Ölçülmesi

\begin{tabular}{|c|c|c|c|c|c|c|c|c|c|c|c|c|c|c|c|c|c|}
\hline İller & $\begin{array}{c}\text { SEGE } 2011 \\
\text { Endeksi }\end{array}$ & $\begin{array}{l}\text { SEGE } 2011 \\
\text { Sira (1) }\end{array}$ & \begin{tabular}{|l} 
IGE 2013 \\
Endeksi
\end{tabular} & $\begin{array}{c}\text { IGE } 2013 \\
\text { Sira (2) }\end{array}$ & $\begin{array}{l}\text { IGE 2014 } \\
\text { Endeksi }\end{array}$ & $\begin{array}{c}\text { IGE 2014 } \\
\text { Sira (3) }\end{array}$ & (3)-(2) & (3)-(1) & İller & $\begin{array}{c}\text { SEGE } 2011 \\
\text { Endeksi }\end{array}$ & $\begin{array}{l}\text { SEGE 2011 } \\
\text { Sira (1) }\end{array}$ & $\begin{array}{l}\text { İGE } 2013 \\
\text { Endeksi }\end{array}$ & $\begin{array}{l}\text { IGE } 2013 \\
\text { SIra (2) }\end{array}$ & $\begin{array}{c}\text { İGE } 2014 \text { En- } \\
\text { deksi }\end{array}$ & $\begin{array}{l}\text { IGE 2014 } \\
\text { Sura (3) }\end{array}$ & (3) - (2) & (3) - (1) \\
\hline Adana & 0,567 & 16 & 0,710 & 37 & 0,737 & 46 & 9 & 30 & Kahramanmaraş & $-0,468$ & 60 & 0,677 & 60 & 0,712 & 61 & 1 & 1 \\
\hline Adiyaman & $-0,960$ & 66 & 0,662 & 63 & 0,709 & 64 & 1 & -2 & Karabük & 0,292 & 28 & 0,762 & 5 & 0,762 & 23 & 18 & -5 \\
\hline Afyonkarahisar & $-0,080$ & 43 & 0,688 & 48 & 0,726 & 54 & 6 & 11 & Karaman & 0,186 & 32 & 0,712 & 31 & 0,763 & 22 & -9 & -10 \\
\hline Ağrr & $-1,637$ & 79 & 0,544 & 81 & 0,617 & 81 & 0 & 2 & Kars & $-1,092$ & 68 & 0,630 & 69 & 0,684 & 69 & 0 & 1 \\
\hline Aksaray & $-0,367$ & 55 & 0,656 & 66 & 0,716 & 58 & -8 & 3 & Kastamonu & $-0,147$ & 47 & 0,684 & 53 & 0,742 & 40 & -13 & -7 \\
\hline Amasya & 0,051 & 37 & 0,698 & 43 & 0,755 & 28 & -15 & -9 & Kayseri & 0,565 & 17 & 0,711 & 34 & 0,753 & 30 & -4 & 13 \\
\hline Ankara & 2,838 & 2 & 0,765 & 4 & 0,809 & 1 & -3 & -1 & Kirrkkale & $-0,069$ & 41 & 0,757 & 8 & 0,752 & 31 & 23 & -10 \\
\hline Antalya & 1,503 & 5 & 0,719 & 29 & 0,776 & 10 & -19 & 5 & Kurklareli & 0,592 & 15 & 0,734 & 14 & 0,773 & 14 & 0 & -1 \\
\hline Ardahan & $-1,138$ & 71 & 0,623 & 71 & 0,704 & 65 & -6 & -6 & Kırşehir & $-0,021$ & 40 & 0,712 & 32 & 0,744 & 38 & 6 & -2 \\
\hline Artvin & $-0,105$ & 44 & 0,729 & 17 & 0,775 & 13 & -4 & -31 & Kilis & $-0,573$ & 63 & 0,696 & 46 & 0,697 & 67 & 21 & 4 \\
\hline Aydın & 0,560 & 19 & 0,720 & 25 & 0,75 & 34 & 9 & 15 & Kocaeli & 1,659 & 4 & 0,759 & 7 & 0,795 & 2 & -5 & -2 \\
\hline Balikesir & 0,476 & 22 & 0,711 & 36 & 0,756 & 27 & -9 & 5 & Konya & 0,531 & 20 & 0,696 & 47 & 0,74 & 42 & -5 & 22 \\
\hline Bartın & $-0,198$ & 48 & 0,661 & 64 & 0,736 & 48 & -16 & 0 & Kütahya & 0,020 & 38 & 0,725 & 23 & 0,746 & 36 & 13 & -2 \\
\hline Batman & $-1,120$ & 70 & 0,636 & 67 & 0,68 & 72 & 5 & 2 & Malatya & $-0,078$ & 42 & 0,711 & 35 & 0,736 & 49 & 14 & 7 \\
\hline Bayburt & $-0,595$ & 64 & 0,678 & 58 & 0,719 & 57 & -1 & -7 & Manisa & 0,471 & 23 & 0,723 & 24 & 0,748 & 35 & 11 & 12 \\
\hline Bilecik & 0,363 & 27 & 0,753 & 9 & 0,783 & 7 & -2 & -20 & Mardin & $-1,359$ & 74 & 0,627 & 70 & 0,682 & 71 & 1 & -3 \\
\hline Bingöl & $-1,192$ & 72 & 0,599 & 75 & 0,683 & 70 & -5 & -2 & Mersin & 0,464 & 24 & 0,719 & 27 & 0,751 & 32 & 5 & 8 \\
\hline Bitlis & $-1,400$ & 76 & 0,594 & 76 & 0,666 & 75 & -1 & -1 & Muğla & 1,049 & 8 & 0,742 & 13 & 0,779 & 9 & -4 & 1 \\
\hline Bolu & 0,639 & 11 & 0,767 & 3 & 0,788 & 4 & 1 & -7 & Muş & $-1,733$ & 81 & 0,570 & 78 & 0,645 & 78 & 0 & -3 \\
\hline Burdur & 0,368 & 26 & 0,719 & 28 & 0,758 & 25 & -3 & -1 & Nevş̧ehir & 0,103 & 36 & 0,720 & 26 & 0,739 & 43 & 17 & 7 \\
\hline Bursa & 1,374 & 6 & 0,728 & 19 & 0,771 & 16 & -3 & 10 & Niğde & $-0,376$ & 56 & 0,711 & 33 & 0,729 & 51 & 18 & -5 \\
\hline Çanakkale & 0,600 & 14 & 0,730 & 15 & 0,769 & 17 & 2 & 3 & Ordu & $-0,481$ & 61 & 0,681 & 57 & 0,727 & 53 & -4 & -8 \\
\hline Çankırı & $-0,331$ & 54 & 0,685 & 52 & 0,737 & 47 & -5 & -7 & Osmaniye & $-0,289$ & 53 & 0,681 & 56 & 0,726 & 55 & -1 & 2 \\
\hline Çorum & $-0,240$ & 50 & 0,687 & 50 & 0,728 & 52 & 2 & 2 & Rize & 0,155 & 34 & 0,727 & 20 & 0,776 & 11 & -9 & -23 \\
\hline Denizli & 0,912 & 10 & 0,745 & 11 & 0,764 & 20 & 9 & 10 & Sakarya & 0,564 & 18 & 0,725 & 21 & 0,757 & 26 & 5 & 8 \\
\hline Diyarbakır & $-1,001$ & 67 & 0,635 & 68 & 0,676 & 73 & 5 & 6 & Samsun & 0,158 & 33 & 0,704 & 39 & 0,744 & 37 & -2 & 4 \\
\hline Düzce & 0,106 & 35 & 0,685 & 51 & 0,753 & 29 & -22 & -6 & Siirt & $-1,417$ & 77 & 0,617 & 72 & 0,673 & 74 & 2 & -3 \\
\hline Edirne & 0,638 & 12 & 0,728 & 18 & 0,763 & 21 & 3 & 9 & Sinop & $-0,248$ & 51 & 0,688 & 49 & 0,739 & 44 & -5 & -7 \\
\hline Elazı̆̆ & $-0,010$ & 39 & 0,701 & 42 & 0,735 & 50 & 8 & 11 & Sivas & $-0,221$ & 49 & 0,697 & 45 & 0,738 & 45 & 0 & -4 \\
\hline Erzincan & $-0,106$ & 45 & 0,704 & 38 & 0,761 & 24 & -14 & -21 & Şanhlurfa & $-1,280$ & 73 & 0,606 & 74 & 0,641 & 79 & 5 & 6 \\
\hline Erzurum & $-0,433$ & 59 & 0,672 & 61 & 0,703 & 66 & 5 & 7 & Şırnak & $-1,461$ & 78 & 0,553 & 80 & 0,657 & 76 & -4 & -2 \\
\hline Eskişehir & 1,167 & 7 & 0,774 & 1 & 0,785 & 6 & 5 & -1 & Tekirdağ & 0,915 & 9 & 0,713 & 30 & 0,771 & 15 & -15 & 6 \\
\hline Gaziantep & 0,268 & 30 & 0,667 & 62 & 0,71 & 62 & 0 & 32 & Tokat & $-0,382$ & 57 & 0,682 & 55 & 0,716 & 60 & 5 & 3 \\
\hline Giresun & $-0,256$ & 52 & 0,703 & 41 & 0,743 & 39 & -2 & -13 & Trabzon & 0,222 & 31 & 0,744 & 12 & 0,775 & 12 & 0 & -19 \\
\hline Gümüşhhane & $-0,481$ & 62 & 0,678 & 59 & 0,716 & 59 & 0 & -3 & Tunceli & $-0,389$ & 58 & 0,683 & 54 & 0,768 & 18 & -36 & -40 \\
\hline Hakkari & $-1,696$ & 80 & 0,565 & 79 & 0,656 & 77 & -2 & -3 & Uşak & 0,374 & 25 & 0,704 & 40 & 0,75 & 33 & -7 & 8 \\
\hline Hatay & $-0,130$ & 46 & 0,698 & 44 & 0,723 & 56 & 12 & 10 & Van & $-1,378$ & 75 & 0,581 & 77 & 0,634 & 80 & 3 & 5 \\
\hline Ĭğdır & $-1,118$ & 69 & 0,610 & 73 & 0,689 & 68 & -5 & -1 & Yalova & 0,626 & 13 & 0,767 & 2 & 0,78 & 8 & 6 & -5 \\
\hline Isparta & 0,527 & 21 & 0,759 & 6 & 0,766 & 19 & 13 & -2 & Yozgat & $-0,608$ & 65 & 0,656 & 65 & 0,709 & 63 & -2 & -2 \\
\hline İstanbul & 4,515 & 1 & 0,725 & 22 & 0,795 & 3 & -19 & 2 & Zonguldak & 0,276 & 29 & 0,730 & 16 & 0,741 & 41 & 25 & 12 \\
\hline İzmir & 1,971 & 3 & 0,753 & 10 & 0,785 & 5 & -5 & 2 & & & & & & & & & \\
\hline
\end{tabular}

Ek-8: İGE 2014'ün Diğer Çalışmalar ile Karşılaştırılması 
Mustafa Caner Meydan, Hacettepe Üniversitesi İstatistik Bölümü lisans derecesini 2005 yılında ve Gazi Üniversitesi İşletme yüksek lisans derecesini 2013 yılında almıştır. Halen ABD Duke Üniversitesi Uluslararası Kalkınma Politikası yüksek lisans ve Hacettepe Üniversitesi İktisat doktorasına devam etmektedir. Profesyonel iş hayatında Kültür ve Turizm Bakanlığı, Ziraat Bankası ve Kalkınma Bakanlığı'nda (mülga Devlet Planlama Teşkilatı) görev yapmıştır. Halen Sanayi ve Teknoloji Bakanlığı'nda Sanayi ve Teknoloji Uzmanı olarak görev yapmaktadır. OECD ve Dünya Bankası projelerinde görev almış, ulusal ve uluslararası toplantılarda sunumlar gerçekleştirmiştir. 2013 yılında yayımlanan "illerin ve Bölgelerin SosyoEkonomik Gelişmişlik Sıralaması Araştırması (SEGE-2011)"nın yazarlarındandır. Ayrıca, bölgesel analizler, izleme-değerlendirme ve etki değerlendirme/analizi konularında makale ve rapor çalışmaları bulunmaktadır. Politika analizi; izleme, değerlendirme ve etki değerlendirme/analizi ile istatistiksel ve bölgesel analizler konularında uzmanlaşmıştır.

Mustafa Caner Meydan, He received his undergraduate degree in 2005 from Hacettepe University, Faculty of Science, Department of Statistics and his master's degree in Business Administration in 2013 from Gazi University. Currently, he is studying for his second Master degree in International Development Policy at Duke University and Economics PhD at Hacettepe University. In his professional life, he worked at Ministry of Culture and Tourism, Ziraat Bank and Ministry of Development (prior State Planning Organization). He is currently working as an Industry and Technology expert at Ministry of Industry and Technology. He was involved in OECD and World Bank projects, made presentations at national and international organizations. He is a co-author of Socio-Economic Development Index published in 2013. He has papers and reports on regional analyses, monitoring-evaluation, and impact evaluation. He specializes in policy analysis, monitoring-evaluation, impact evaluation, and statistical and regional analyses.

E-mail: mustafa.meydan@duke.edu

Volkan İdris Sarı, Ortadoğu Teknik Üniversitesi Şehir ve Bölge Planlama lisans derecesini 2003 yılında almıştır. 2004 yılında Devlet Planlama Teşkilatı'nda uzman yardımcısı olarak çalışmaya başlamıştır. AB destekli bölgesel kalkınma programları, izleme ve değerlendirme sistemleri ve bölgesel kalkınma ajansları alanlarında koordinatör olarak çalışmıştır. 2009 yılında yazdığı “Proje Döngüsü Yönetiminde Etkililik Değerlendirmesi" tezi ile Planlama Uzmanı unvanını almıştır. 2013 yılında Carnegie Mellon Üniversitesi Kamu Yönetimi yüksek lisans programını tamamlamıştır. 2013 yılından itibaren mülga Kalkınma Bakanlığı Kentsel ve Mekânsal Gelişme Dairesinde uzman olarak çalışmıştır. Bölgesel kalkınma, izleme ve değerlendirme, kentsel gelişme ile kalkınma iktisadı alanlarında araştırmalar yürütmüş, makale ve raporları yayımlamıştır. Şu an Sanayi ve Teknoloji Bakanlığı Kalkınma Ajansları Genel Müdürlügünde uzman olarak çalışmaktadır. Halen Ankara Üniversite'sinde Beşeri ve İktisadi Coğrafya alanında doktora çalışmasına devam etmektedir.

Volkan İdris Sarı, He received his bachelor's degree in City and Regional Planning from Middle East Technical University in 2003. In 2004, he started to work as an assistant expert in the State Planning Organization. He has worked as a coordinator in the field of regional development programs, monitoring and evaluation systems and regional development agencies. He promoted as the Planning Expert 
in 2009 by completing his thesis on "Effectiveness Evaluation in Project Cycle Management". In 2013, he has completed mster program in Public Administration at Carnegie Mellon University. Since 2013, he worked as a urban specialist in the Department of Urban and Spatial Development of the Ministry of Development. He has conducted researches and published several articles and reports on the areas of regional development, monitoring and evaluation, urban development and development economics. Now he is working as an expert at the General a Industry and Technology expert He is currently a PhD candidate in Humanities and Economic Geography at Ankara University.

E-mail: volkanidris.sari@sanayi.gov.tr

\section{Kaynakça Bilgisi / Citation Information}

Meydan, M. C. ve Sarı, V. İ. (2018). İnsani Gelişme Endeksi ve Alt Endekslerinin Türkiye'deki İller İçin Ölçülmesi. IDEALKENT - Kent Araştırmaları Dergisi, 24, 387-429 